\title{
U.S. Banking Deregulation, Small Businesses, and Interstate Insurance of Personal Income
}

\author{
Yuliya Demyanyk \\ University of Houston
}

\author{
Charlotte Ostergaard \\ Norwegian School of Management \\ and Norges Bank
}

\author{
Bent E. Sørensen \\ University of Houston and CEPR
}

This version: June 2006

\begin{abstract}
We estimate the effects of deregulation of U.S. banking restrictions on the amount of interstate personal income insurance during the period 1970-2001. Interstate income insurance occurs when personal income reacts less than one-to-one to state-specific shocks to output. We find that income insurance improved after banking deregulation, and that this effect is larger in states where small businesses are more important. We further show that the impact of deregulation is stronger for proprietors' income than other components of personal income. Our explanation of this result centers on the role of banks as a prime source of small business finance and on the close intertwining of the personal and business finances of small business owners. Our analysis casts light on the real effects of bank deregulation, on the risk sharing function of banks, and on the integration of bank markets.
\end{abstract}

Keywords: Financial deregulation, integration of bank markets, interstate risk sharing, small business finance. 


\section{Introduction}

Since the 1970s, the structure of the U.S. banking industry has changed considerably following deregulation of restrictions on branching and interstate banking. The ensuing wave of consolidation has increased the average bank company size and allowed banks to expand into new geographical markets by operating larger branch networks or bank holding companies. Banks play a central role in the allocation of capital in the economy and is the prime source of finance to small businesses, and we examine if these changes in bank market structure has had real effects for small business owners. ${ }^{1}$ In particular, we examine whether interstate personal income insurance increased after deregulation: we compare income insurance in states where small businesses are respectively more and less prevalent and we consider the sensitivity of proprietors' income to state-level output shocks. By income insurance, we mean the extent to which, in a given state, state-specific personal income fluctuates with state-specific shocks to output. In states that are financially integrated with other states, agents may trade claims on output (e.g., equity or direct investments) across state borders, thereby sharing state-specific risks with residents of other states, insulating personal income from fluctuations in state-level output. Through transactions with intermediaries such as banks, agents share output risks indirectly via the contracts they hold with the bank, and banks, in turn, share risk with other states. If banking deregulation has improved integration of previously separated bank markets, interstate income insurance may well have improved.

The effect of banking deregulation on income insurance is estimated using annual statelevel data for the period 1970-2001. We first establish that banking deregulation has a positive effect on income insurance overall using four alternative measures of deregulationtwo measures of intrastate banking deregulation and two measures of interstate banking deregulation. From regressions which do not control for other potential determinants of risk sharing, the marginal effect of deregulation is in excess of 10 percentage points, in the sense that an additional 10 percent, or more, of a state-specific output shock is smoothed on average. Furthermore, we find that the impact of deregulation is larger in states where small businesses are more prevalent: in states with many small businesses the improvement in income insurance is in the order of 20 percentage points. Our results suggest that bank consolidation within deregulated states is particularly important for this effect. We

\footnotetext{
${ }^{1}$ We define small businesses as those having less than 100 employees - with this definition, small businesses comprise an important part of the economy. In the average state, businesses with less then 100 employees made up 58 percent of total employment in 1978. (The Small Business Administration defines small businesses as having less than 500 full-time equivalent employees.)
} 
explore whether other contemporaneous developments in financial markets may explain the estimated increase in risk sharing and find that, in particular, the higher impact of deregulation on risk sharing in states with more small businesses is a robust result. We provide additional evidence for our hypothesis by showing that the impact of banking reform is considerably larger for proprietors' income than for other components of personal income.

Banking deregulation have mainly taken two forms: intrastate deregulation, which allowed banks to branch statewide, and interstate deregulation which allowed the formation of multi-state bank holding companies. While the labels may suggest that inter-state deregulation should be the main determinant of inter-state risk sharing, in fact, banking deregulations may improve risk sharing in several ways. First, deregulation may affect the interaction between small firms and their banks and, second, banks may share risk better with out-of-state agents such as banks or individuals after reforms. We discuss these dimensions in turn.

The informational opaqueness of small businesses without an established reputation for quality prevents them from raising arm's-length finance in public markets. Banks, on the other hand, may mitigate such informational asymmetries through repeated interaction and monitoring (Diamond (1984, 1991), and Rajan (1992)). When a bank provides finance to a firm, it shares risk with the firm's owners by bearing a part of the firm's output risk. This may be especially important for small businesses as they depend on bank loans for their operations. In contrast, when a business is entirely self-financed by the owner, the owner bears all output risk himself and cannot insure his personal income from shocks to his business. This is reflected in the cross-sectional pattern of state-level income insurance that we establish: states with many small businesses exhibit a lower average level of income insurance. The finding is consistent with Agronin (2003), who finds that income insurance is lower in states where proprietors' income makes up a larger share of personal income.

Banking deregulation may have improved the insurance of personal income by increasing the availability of small business finance, whether to new or existing borrowers. Alternatively, even if the total volume of small business loans were unchanged, banking deregulation may have altered banks' pattern of lending, allowing small business owners to further the separation of their personal finances from those of their firm. This latter channel points to the importance of bank-borrower relationships for the efficiency of the capital allocation process. In a valuable bank-borrower relationship, the bank may have incentives to offer (self-enforcing) implicit contracts that facilitate insurance, for example through the continued extension of credit during bad times (Allen and Gale (2000) and Boot (2000)). Each of these two channels would work to lower the correlation between output and personal 
income. Intrastate deregulation, which removed barriers to competition among banks is likely to be particularly relevant for small business lending.

Along the other dimension, banking reform affects interbank risk sharing as a result of mergers and acquisitions across state borders and the formation of multi-state bank holding companies. Houston, James, and Marcus (1997) demonstrate that bank holding companies manage capital and liquidity at the consolidated level. However, also mergers within state borders affect risk sharing. Intrastate mergers create larger banks which are typically more integrated in national markets than small local banks. For example, a large bank such as Citibank has extensive nation-wide (indeed, world-wide) operations compared to a small town savings bank. Furthermore, banks share risk with other banks and financial institutions by borrowing and lending in U.S.-wide interbank and money markets. Banks may borrow and lend out-of-state in order to help stabilize income of small business owners. ${ }^{2}$ Hence, bank actions may affect income insurance also without explicit multi-state crossownership between banks. ${ }^{3}$

The disproportionate increase in income insurance that we find for states with many small businesses is striking. We conjecture that deregulation may have altered the pattern of banks' small business lending in two ways: 1) improved efficiency of the banks operating after deregulation leading to, e.g., better screening or monitoring of small business borrowers, or financially less constrained banks which have more leeway for sharing risk within small businesses, and 2) improved efficiency of interbank capital allocation, in the sense that deregulation improved banks' ability to share risks amongst themselves, the benefits of which were passed on to small business borrowers. We discuss the empirical evidence underlying these conjectures in Section 4.

Call Report data on small business lending by U.S. banks has been reported only since 1993. ${ }^{4}$ Hence, we cannot directly test for changes in banks' patterns of small business lending following deregulation. However, we provide evidence that state-specific personal

\footnotetext{
${ }^{2}$ For example, banks in an agricultural state can stabilize income in that state by borrowing in the face of adverse weather shocks.

${ }^{3}$ Banking deregulation may have affected interstate income insurance in other ways which are not necessarily related to small businesses. One channel may work through the capital income of households. Personal income have been smoothed through households' capital income if changes in the size of bank organizations smoothed income streams earned by owners of securities issued by banks. Banks are owned, perhaps indirectly, by individual stock holders who ultimately bear the risk of the banks' operations. When stock holders live out-of-state, this results in interstate income insurance. Alternatively, multi-state bank organizations may disperse the effect of state-specific shocks to the banking industry itself throughout the organization. For example, following losses in one state, layoffs and cost-cuttings may be extended to subsidiaries and branches in other states. Or further, if bank finance makes it easier for firms to raise external non-bank finance, banking deregulation may have helped smooth dividends paid by such firms.

${ }^{4}$ See, e.g., Wolken (1998).
} 
income is smoothed more following deregulation and that this improvement in income insurance is stronger in states with a relatively high prevalence of small businesses. We also demonstrate that proprietors' income became less pro-cyclical following deregulation. These patterns are consistent with our hypothesis that banks' small business lending is important for the insurance of small business owners' income and that this channel of income insurance became more effective following deregulation.

Other papers have documented the real effects of branching deregulations in the United States. In an important contribution, Jayaratne and Strahan (1996) show that state per capita growth increased in states that deregulated, both when measured in terms of personal income and state GDP. ${ }^{5}$ Our findings are closely related to those of Jayaratne and Strahan as both papers identify banking deregulation as an impetus for an economic process with significant real effects at the macro level. In this paper, we identify the link between banks' insurance role in the financing of small businesses as a potential channel of welfare gain from bank integration. Petersen and Rajan (1994) find evidence that small businesses in the United States benefit from lending relationships and our results complement theirs by pointing to the value of bank relationships in small businesses finance.

Our paper is also related to research on the integration of U.S. states. Morgan, Rime, and Strahan (2004) find that consolidation into multi-state bank holding companies has lowered state output volatility and made state business cycles more alike. Asdrubali, Sørensen, and Yosha (1996) study income insurance through cross-regional holdings of debt and equity ("capital market income smoothing") and through the super-regional tax-transfer system ("federal government income smoothing"). ${ }^{6}$

The rest of the paper is organized as follows. Section 2 presents and discusses the premises for our hypothesis that the effect of banking deregulation on interstate income insurance is particularly strong for small business owners. Section 3 briefly presents the history of banking deregulation in the United States. Section 4 discusses in more detail the channels through which deregulation may affect the insurance of state-specific personal income and Section 5 considers issues of robustness. Section 6 describes our data, Section 7 presents our measure of interstate income insurance, and Section 8 presents the empirical

\footnotetext{
${ }^{5}$ They also demonstrate that branching deregulations are exogenous to state-level growth, that is, states did not tend to deregulate in the expectation of an imminent economic upturn.

${ }^{6}$ Atkeson and Bayoumi (1993) seem to have been the first to bring up the issue of income insurance across U.S. states through private capital markets. See also Crucini (1999) for another early paper on risk sharing across U.S. states. Sala-i Martin and Sachs (1992) suggest that the federal government in the United States provides substantial income insurance to states through procyclical taxes and countercyclical transfers. That paper, and many following it, has focussed on U.S. states as members of a successful currency union (the United States) that should be studied as a model for the formation of currency unions such as the European Monetary Union.
} 
results. Section 9 concludes.

\section{Small business finance and U.S. evidence}

Our hypothesis, that personal income insurance improved after deregulation through banks' small business lending, builds on two fundamental observations: 1) small firms depend heavily on bank-intermediated finance, 2) owners' financial position is closely intertwined with that of their business. ${ }^{7}$ In the following, we discuss this evidence and its relation to our hypothesis.

It is well-established empirically that bank-intermediated finance is one of the main sources of small business funding in the United States. For example, Berger and Udell (1998) present evidence from the 1993 National Survey of Small Business Finance (NSSBF) which demonstrates that small businesses rely heavily on commercial bank finance from their very first years. According to the survey, bank debt constitutes 16 percent of total assets for "infant" (0-2 years) firms, and 31 percent of "adolescent" (3-4 years) firms. For older firms, the ratio is 17 percent (on average). This is compared to total equity stakes of 48 percent, 39 percent and 52 percent, respectively (ibid, table 1, p. 620). Commercial bank debt is, overall, the most important external source of finance. ${ }^{8}$

An important characteristic of small business finance is the intertwining of business owners' financial position with that of their business. Hence, funds (mostly in the form of equity) provided by the principal owner is the most important source, amounting to 35 percent of all funding (overall). Trade credit is the third most important source of funds. Furthermore, outside finance often has personal commitments attached. Avery et al. (1999) report that 80 percent of the small firms which have loans, have loans with personal commitments. ${ }^{9}$ Ang (1992) reports that about 40 percent of small business loans and 60 percent of loan dollars are guaranteed and/or secured by personal assets. Berger and Udell (1998) find that 90 percent of commercial bank debt is secured.

The 1993 NSSBF also documents the importance of finance, esp. equity, from insider sources other than the owner, that is, from family, friends and other people involved in

\footnotetext{
${ }^{7}$ Ang (1992), Berger and Udell (1998), and Avery, Bostic, and Samolyk (1999).

${ }^{8}$ The most common form of small business debt supplied by commercial banks - constituting 56 percent of total small business debt-is lines of credit. The next most important loan types are mortgage and equipment loans, 15 percent and 10 percent, respectively (Berger and Udell (1998)).

${ }^{9}$ That is, loans with either personal collateral or a personal guarantee attached. In the case of personal collateral, the creditor holds a prioritized claim on specific assets of the borrower and controls the use of the assets. A personal guarantee is a more general claim on personal wealth which places fewer restrictions on the guarantor's use of his wealth. The figures are based on the 1987 and 1993 NSSBF and the Survey of Consumer Finances.
} 
the business. Such equity was the second most important source of equity, constituting 13 percent of total assets (Berger and Udell (1998)).

The above observations are, of course, consistent with the notion that agency conflicts rooted in asymmetries of information are severe for small businesses. As noted above, the interpretation of our results centers on the dependency of small businesses on bank intermediated finance. ${ }^{10}$ It is exactly because the average small business has no real substitutes for bank finance, other than own funds or funds raised from family and friends, that part of the efficiency gain from banking deregulation is likely to work through small businesses. Through the requirement of part self-financing, collateral and guarantees, and through monitoring and repeated interaction over time, banks may mitigate problems of adverse selection and moral hazard. ${ }^{11}$

Banking deregulation may have improved personal income insurance by increasing the availability of small business loans or by altering the lending pattern of banks. For illustration, consider an entirely self-financed sole proprietorship. In this case, the small business owner bears all the firms output risk himself-shocks to the surplus created in the firm will be transferred one-to-one to his personal income. When the owner obtains external finance, the linkage between his personal finances and those of the business is relaxed and the covariation of personal income with output may fall. Banks may share risk with the owner by avoiding initiation of formal bankruptcy procedures or liquidation of assets when the business hits hard times, allowing the borrower to fall behind with payments of interest and installments. ${ }^{12}$ When businesses default, banks share risk by absorbing part of the losses. Furthermore, the availability of external finance may help small business owners smooth their income to the extent it furthers diversification of the owners' sources of income. It may facilitate accumulation of savings outside the business, e.g., in housing or financial investments, generating a stream of future income that is less than perfectly correlated with the success of the business.

\footnotetext{
${ }^{10}$ Although venture and angel finance are substitutes for some small firms, the above studies show that in terms of magnitude, these sources do not represent a real alternative to bank finance for the average firm.

${ }^{11}$ See also Leland and Pyle (1977), Bester (1985), Besanko and Thakor (1987), and Holmstrom and Tirole (1997).

${ }^{12}$ In a study of U.K. firms in distress, Franks and Sussman (2005) find that banks typically attempt to rescue the firms as opposed to immediate liquidation. However, banks often contract lending during distress. While the U.K. may differ from the United States due to differences in bankruptcy laws this direct evidence is, at least, suggestive of similar behavior in the United States.
} 


\section{The history of U.S. banking deregulation}

Regulations regarding banks' ability to branch and operate holding company structures has been subjected to state legislation since the $1920 \mathrm{~s} .{ }^{13}$ Many states imposed restrictions on these bank activities both within and across state borders. During the 1980s and 1990s, however, restrictions were gradually lifted in almost all states.

Until the 1980s, most states imposed some form of intrastate branching restrictions. That is, legislation either completely prohibited branching within the state or restricted the geographical area in which a bank could open branches, for example, branching would be allowed in the county of the head office only. In 1985, statewide branching was limited in 26 states, and even at the end of 1990, five states still upheld restrictions. ${ }^{14}$

Branching restrictions took two forms: the first was directed at banks' ability to branch through mergers and acquisitions, preventing a bank or a bank holding company from acquiring another bank and converting it into a branch. A bank holding company may establish a group of subsidiary banks as a substitute for a branching network, but with several drawbacks. Subsidiary banks must operate separate boards and be individually capitalized, restricting loan limits. Also, the holding company structure incurs certain administrative costs associated with filing requirements to regulators (Amel and Liang (1992)). Such differences enables a branching network to realize economies of scale that a holding company structure may not. ${ }^{15}$ The second form of regulations imposed limits on the opening of new (de novo) branches, protecting banks from entry by outside banks.

Differences in states' willingness to allow branch networks sustained the development of very differently structured bank systems across states. Where some states allowed only unit banking, other states permitted statewide branching. Branching restrictions, especially on de novo branching, often took the form of home office protection laws, prohibiting a bank from establishing a branch in an area in which the principal (home) office of another bank was located, without the written consent of that bank. Areas with home office protection were typically small towns or rural areas with a population below a certain number. ${ }^{16}$

\footnotetext{
${ }^{13}$ The McFadden Act of 1927 essentially prohibited intrastate branching by subjecting the branching of national banks to state authority. The Douglas Amendment to the Bank Holding company Act of 1956 further restricted interstate expansion by barring bank holding companies from acquisitions in another state unless specifically authorized by that state.

${ }^{14}$ Arkansas, Colorado, Illinois, Minnesota, and New Mexico.

${ }^{15}$ Several states, in fact, also prohibited the formation of (intrastate) multi-bank holding companies during the first half of the sample. Except for Missouri all states had removed such prohibitions in 1985.

${ }^{16}$ For example, in Connecticut, home office protection applied to de novo branching but not to branching through mergers and acquisitions. In 1986, statewide branching was allowed only into towns with a population of 100,000 or more. In 1987, the limit was lowered in 60,000 and it was completely removed in 1988 . Minnesota, in 1977, permitted two detached facilities in the municipality of the principal office or within 25
} 
Effectively, such laws gave many small community banks home turf, shielding them from competitive pressures. At the same time, banks' inability to diversify their portfolios geographically created a close interdependency between the local economy and the health of local banks.

When states began relaxing branching restrictions, typically branching by mergers or acquisitions were authorized earlier than de novo branching. In fact, more than 10 states only permitted statewide de novo branching well into the 1990s. ${ }^{17}$ Considerable consolidation, predominantly through mergers and acquisitions, followed states' deregulations. Many bank holding companies jumped at the opportunity to convert their organization into a branching network (e.g., McLaughlin (1995)) and the number of small community banks dropped considerably as they were attractive buy-out targets. At the beginning of our sample, the share of assets held by very small banks - banks with less than 25 million 1982-dollars in assets - was 35 percent. At the end of our sample this fraction had dropped to 0.6 percent. ${ }^{18}$ As a result, banks' average size increased. Increased competitive pressure, geographic diversification, and scale-economies on both the loan- and deposit-side, affected loan losses and the cost of capital, and hence loan interest rates. Jayaratne and Strahan (1998) find that relaxation of intrastate branching restrictions were the source of large improvements in the efficiency of bank lending allowing better-run banks to capture a larger share of local markets. Low-cost banks grew faster than under-performing banks following deregulation and state averages for loan losses and operating expenses fell. Jayaratne and Strahan show that efficiency gains were passed on to borrowers as banks' average interest income per loan fell. ${ }^{19}$ Large banks pursued branching aggressively but also some community banks engaged in branching in order to stay competitive (Wirtz (2005)).

There is evidence that consolidation spurred new branching in local bank markets. Berger, Bonime, Goldberg, and White (1999) demonstrate that mergers and acquisitions explain 20 percent of subsequent de novo entry in metropolitan markets and 10 percent in rural markets, consistent with the suggestion that the reduction in small business lending

miles of the principal office, unless such location was in a municipality with a population less than 10,000 and different from that of the principal office, in which case written consent from incumbent banks was required. While the limit on the number of branches was later relaxed, the home office protection rule for municipalities of less than 10,000 population is still in place today.

${ }^{17}$ Kroszner and Strahan (1999) analyze the determinants of bank deregulation and find that states with more financially unstable banks tended to deregulate earlier. Also, states with many small firms deregulated earlier, consistent with our hypothesis that deregulation-induced competition may be particularly important for small firms.

${ }^{18}$ Authors' calculations from call report data.

${ }^{19}$ They estimate that average loan rates fell by an amount corresponding to three-fifths of the reduction in loan losses and only find small, generally statistically insignificant, increases in bank profitability after deregulation. 
due to consolidation is partly replaced by lending of new entrants. For example, Wirtz (2005) reports that many smaller banks have reportedly branched into previously unbanked communities in the states of Montana and North Dakota.

Also interstate banking restrictions were common in many states. Entry by bank holding companies chartered in other states was only gradually permitted by individual states during the 1980s. Maine was the first state to allow entry by out-of-state bank holding companies in 1978 and was followed by other states in the 1980s. Typically, acquisitions by out-of-state bank holding companies were limited to banks from same-region states and subject to reciprocity, that is, entry was only permitted if the acquiring banks' home state allowed entry by banks from the target state, although some states were open to nationwide entry. Reciprocity was often a regional phenomenon, that is, states in, say, the north-eastern region of the U.S. would mutually allow entry. Most states, at first, permitted only entry by mergers and acquisitions (as opposed to de novo). ${ }^{20}$

McLaughlin (1995) documents that the deregulation of intrastate branching restrictions caused changes in market structure faster than interstate banking restrictions. Banks' responses to interstate deregulations were slower but picked up considerable speed in the late 1980s, although bank holding companies tended to expand intra-regionally, rather than cross-regionally.

Finally, interstate branching was permitted nationwide with the Reigle-Neal Interstate Banking and Branching Efficiency Act, which became effective June 1997, although states had the opportunity to opt in at an earlier date. As the date of this act falls at the very end of our sample, we do not consider interstate branching deregulations in our empirical analysis.

\section{Channels of improvements in personal income insurance}

Banking deregulation may have improved interstate income insurance if either the level of bank intermediated finance to small businesses increased or the pattern of supply changed. Improved integration of bank markets caused by changes in banks' reach, organization, and size, likely affected banks' costs and ability to share risks. In this section, we present and discuss existing empirical evidence on which we base our conjecture that changes in the

\footnotetext{
${ }^{20}$ For example, in 1987 Alabama allowed reciprocal entry by out-of-state bank holding companies from the states of AR, DC, FL, GA, KY, LA, MD, MS, NC, SC, TN, VA, and WV. Acquired banks had to be at least five years old and could not branch across county lines for seven years after acquisition. De novo entry was prohibited. Furthermore, acquiring holding companies had to hold at least 80 percent of their deposits in the region. In 1988, the group is expanded to include TX and, in 1995, Alabama allowed national interstate banking on a non-reciprocal basis.
} 
pattern of lending play an important role for the effect of deregulation on the smoothing of personal income and the link to small businesses.

\subsection{Geographical diversification and bank efficiency}

Geographical diversification may have improved banks' ability to bear (idiosyncratic) credit risk. Diversified banks are likely to operate with fewer financial constraints and are less sensitive to local recessions, increasing their ability to share risk with their borrowers. Demsetz and Strahan (1997) show that better diversification in large bank holding companies permits operation with higher leverage and more business loans in the portfolio. This is also related to bank size: larger banks facilitate income insurance through geographical diversification of their loan portfolios whereas the lending behavior of smaller banks will be more closely tied in with the health of the local economy.

Deregulation may have altered the lending behavior of banks if incumbent banks in previously protected markets were operating inefficiently and deregulation permitted the entry of better managed banks. If entering banks were superior in the screening of potential borrowers' prospects and lend to firms with higher net present value projects, more high quality borrowers would have been financed. Jayaratne and Strahan (1996) argue that average bank efficiency improved after deregulation and show that losses on banks' loan portfolios fell-poorly operating banks were either absorbed or squeezed out of the market.

\subsection{Internal capital markets in bank holding companies}

Banks that belong to a multi-bank organization may benefit by establishing internal capital markets, reallocating capital among subsidiaries, and share risks with borrowers at a lower cost. Houston and James (1998) show that unaffiliated banks are more cash-flow constrained than banks affiliated with a holding company. Ashcraft (2001) argues that banks affiliated with a holding company have better access to external fund, and similarly finds that standalone banks face more severe financial constraints than affiliated banks. As a consequence, in states where stand-alone banks have more market share, aggregate lending is relatively more affected by monetary policy contractions. Multi-state bank holding companies may enjoy the largest benefits from geographical diversification and benefit more from internal markets. 


\subsection{Bank size and risk sharing among banks}

There is reason to believe that bank size may be related to income insurance. Kashyap and Stein (2000) argue that small banks are at an informational disadvantage in wholesale markets compared to larger banks which are less opaque and better able to overcome problems of asymmetric information. They show that small banks do not use uninsured funds to smooth the effect of monetary policy contractions. ${ }^{21}$ Ostergaard (2001) finds evidence that these frictions are significant at the state level and that (state-level) bank lending in states dominated by small banks is more closely tied to banks' internal liquidity position. This implies that larger banks may have an advantage in the sharing of risks with counterparties in national money and capital markets. It also suggests that larger banks have greater flexibility in their transactions with small business owners. A shift in the size-distribution away from small community banks towards larger banks may therefore increase the scope for income insurance.

\subsection{Changes in the supply of credit to small businesses}

An improvement in interstate income insurance would also be consistent with a general increase in the availability of small business finance following deregulation, for example, because loans enables new investment or the accumulation of other assets, leading to greater cross-state ownership of claims. Call Report data on small business loans by U.S. banks does not exist prior to 1993 and we know of no direct evidence on banks' small business lending prior to this date. Jayaratne and Strahan (1996) study the effect of deregulation on total bank loan growth and find only weak positive effects. It appears that deregulation did not shift the overall supply of loans significantly, although we know little about potential changes in portfolio composition.

Several studies have used post-1993 data to address whether mergers and acquisitions affected the volume of small business lending and their findings are possibly informative about the effects of the reorganizations that took place in the 1980s. Generally, the evidence does not support the notion that small business lending contracted despite consolidation in the banking industry and the fact that larger banks typically carry fewer small business loans on their books than do smaller banks (for prudential and regulatory reasons). On the other hand, there is little evidence to support the opposite conclusion, that small business lending tended to increase. ${ }^{22}$

\footnotetext{
21 "Small banks" means those in the bottom 95-percent of the size distribution.

${ }^{22}$ See Peek and Rosengren (1998), Strahan and Weston (1998), Goldberg and White (1998), and DeYoung (1998).
} 


\subsection{Competition and lending relationships}

Consolidation in the banking industry altered competition between banks and, thereby, the costs and benefits to firms involved in banking relationships. Through the process of lending, banks acquire information about borrowers and an informed bank can use its information monopoly to extract rent from the borrower (Sharpe (1990), Rajan (1992)). Competition between lenders limit the sustainability of implicit contracts and the sharing of intertemporal surplus between borrowers and lenders as found by Petersen and Rajan (1995). On the other hand, Boot and Thakor (2000) argue that increased competition may induce banks to invest relatively more in relationships because the return on relationship lending improves relative to the return on transaction lending. If consolidation lowered competition in deregulated states, it may have improved the value of bank-borrower relationships and banks' willingness to share risks. Alternatively, if deregulation increased competition, relationships may have been affected detrimentally. ${ }^{23}$ Whether deregulation had an impact on income insurance through changes in competition between banks, however, is ultimately an empirical question. Our results suggest that potentially detrimental effects on income insurance, if they exist, are of second order.

\section{Alternative explanations for the increase in income insur- ance}

In this section we examine alternative explanations for the increase in income insurance that we estimate. In particular, we explore potential factors other than banking deregulation which may have helped improve the integration of capital markets.

\subsection{Changes in lending technology}

Petersen and Rajan (2002) document that the nature of small business lending by banks has changed since the 1970s. Technological advances, such as computers and communication equipment, and the advent of intermediaries specializing in the collection and processing of firm specific information, have enabled banks to substitute hard for soft information in the lending process. This has helped advance more data-based lending decisions involving systematic and periodic assessment of borrowers though information about firms' accounts,

\footnotetext{
${ }^{23}$ Considering the effect of interstate branching deregulations starting in 1994, Dick (2003) reports that concentration at the regional level increased, whereas concentration at the urban (MSA) level was unchanged. See also the discussion in Black and Strahan (2002) on the effect of competition on business creation.
} 
their use of trade credit, and the like. Whereas small business lending has traditionally involved the processing of intangible (soft) information, necessitating lending decisions to be made in close geographical proximity to the location of the borrower, the use of new technology has allowed banks to lend at a greater distance. Petersen and Rajan show that the distance between banks and their small business borrowers have been steadily increasing since the $1970 \mathrm{~s}^{24}$

Banks that lend at greater distances help integrate capital markets and improve the sharing of risks. It might also benefit bank dependent borrowers such as small business owners. Lending across state-borders improve interstate insurance because of portfolio diversification effects, as banks bear output risk from borrowers residing in different states. Also, firms would be able to borrow from a wider range of banks which directly affect the availability and cost of finance. Alternatively, obtaining a loan from a distant reputable bank may improve a borrowers' access to other (nonbank) sources of finance (a certification effect).

The trend of increased distance in lending documented by Petersen and Rajan coincides with the sample we use in our study. Hence, if technological changes are correlated with deregulation, it may be that we are measuring the effect of technological change on income insurance rather than the effect of deregulation. If so, we need to allow also for changes in lending technology in our empirical specification.

Kroszner and Strahan (1999) argue that banking deregulation and technological change are correlated. Namely, they argue that deregulation occurred when the benefits enjoyed by private interest groups (small banks and insurance firms) in favor of upholding restrictions were eroded by, among other things, technological innovations that altered the costs and benefits of restrictions. The ability to lend without soft information would be one such innovation. For the improvement in income insurance to be driven by changes in the technology of lending rather than deregulation, the cross-sectional pattern of technological change must coincide with the pattern of deregulation. Essentially, states should deregulate only after banks had already begun lending to out-of-state borrowers and branching restrictions were binding less.

It is, however, plausible that banking consolidation and technological change are related rather than separate trends. If lending procedures based on hard information involve economies of scale, banks need a certain size to reap the benefits, which in turn necessitates consolidation. That is, consolidation proceeds technological change. For example,

\footnotetext{
${ }^{24}$ They estimate that a firm which began borrowing from its lender in the 1990s were approximately 35 percent further away from its lender than an otherwise identical firm which started borrowing in the 1980s.
} 
there are fixed costs in association with auditing borrowers and collecting information from them, in the acquisition and setting up of systems to process and store this information, in the acquisition of information from data providers external to the bank, in the training of employees to work with the system, etc. This is consistent with the observation that large banks tend to lend at greater distances than small banks (Berger et al. 2005).

\subsection{Development of national mortgage markets and expansions in credit card debt}

Consumer credit markets have developed considerably during our sample period. Credit card loans have become widely available and the securitization of mortgage debt have accelerated since 1980 when Government Sponsored Enterprizes were authorized to engage in the issuance of mortgage backed securities. Is it possible that the deepening of these markets (partly) explain our results?

In principle, borrowing on credit markets help smooth consumption rather than personal income (Asdrubali et al. (1996)). However, small business owners may use consumer credit for some firm-related expenditures. Also, they may substitute between different sources of funds by, say, using credit card debt as a buffer during a credit crunch. However, according to the 1993 NSSBF, credit card debt makes up only 0.14 percent of all finance (equity and debt), while in contrast, bank debt, as the largest external source of finance, constituted 19 percent of all finance (Berger and Udell (1998), Table 1). ${ }^{25}$ Hence, the data does not seem to support the hypothesis that greater availability of unsecured credit card debt may be driving our results, because small business owners do not use consumer credit as a source of finance on a scale that may explain the magnitude of income insurance we measure. Furthermore, for this conjecture to be warranted, the improved access to credit card debt would have to be correlated with the cross-sectional pattern of deregulation, which seems unlikely.

Another major development, the emergence of national mortgage markets, may also have facilitated income insurance. The securitization of mortgage loans entails a pooling of risk and increases capital flows between states as households hold these claims through intermediaries such as insurance companies, pension and mutual funds, etc. This implies that securitization may be contributing to the overall positive trend in income insurance that we observe.

The evolution of a liquid secondary market for mortgages has helped shift interest rate

\footnotetext{
${ }^{25}$ The number includes both the firm's and the owner's credit card debt when used for firm purchases.
} 
risk from banks and other institutions originating mortgages to investors in capital markets and may have improved the financial flexibility of those institutions. ${ }^{26}$ To the extent this has had a stabilizing effect on the supply or cost of finance collateralized by real estate, small business owners have benefited too because mortgage loans is a source of small business finance. ${ }^{27}$

For securitization to explain the disproportionate increase in income insurance in states with more small businesses, mortgage debt must have been a sufficiently flexible source of finance for small business owners that it enabled a significant smoothing of income. However, the use of mortgage finance does not seem pervasive enough to explain the considerable increase in income insurance we measure. Berger and Udell (1998) report that mortgage debt used for business purposes constitutes on average 14 percent of debt to financial institutions, which amounts to only four percent of all funding and seven percent of all debt (ibid, Table 2). Also, these figures are from the 1993-NSSBF which is close to the end of our sample where the effect from securitization is likely to be strongest.

If, on the other hand, consolidation improved the ability of banks to benefit from securitization, and these benefits were passed on to bank dependent borrowers, this would constitute a causal effect of deregulation and be fully consistent with our hypothesis. However, one cannot entirely rule out that banks reaped benefits from securitization for reasons unrelated to deregulation. If this is the case, the trend in securitization should be part of our empirical specification.

\section{Data}

We use a panel of variables for the 50 U.S. states minus Delaware and South Dakota for the period 1970-2001. ${ }^{28}$ Below, we describe the main sources of data and the methodology used to construct the variables used in the analysis. As all our measures are in per capita terms, we often omit the term "per capita" for the sake of brevity. Growth rates of real per capita variables are calculated as first differences of natural log of per capita level values. ${ }^{29}$

\footnotetext{
${ }^{26}$ See, e.g., Pennacchi (1988).

${ }^{27} \mathrm{~A}$ negative correlation between mortgage rates and the volume of securitization is often found in empirical work, see, e.g., Kolari, Fraser, and Anari (1998). However, Heuson, Passmore, and Sparks (2001) argue that this relationship may be an effect of reverse causality.

${ }^{28}$ We exclude Delaware and South Dakota from the sample due to laws that provide tax incentives for credit card banks to operate there. As a result, the banking industry in the two states grew much faster than in other states in the 1980s.

${ }^{29}$ We deflate output using the consumer price deflator rather than the output deflator because we want to measure the purchasing power of output.
} 
State Gross Domestic Product: We use the Bureau of Economic Analysis (BEA) data for gross state product which is defined as the "value added" of the industries of a state deflated by the consumer price index to obtain real per capita state gross domestic product which for brevity we will refer to simply as "gross state product" (GSP).

Personal Income: We use BEA state-level personal income deflated by consumer prices to obtain real per capita personal income by state. ${ }^{30}$ Measures of components of personal income; proprietors' income, wages, and dividends, interest and rental income are also taken from the BEA.

Intrastate branching restrictions: We measure the direct effect of branching deregulation using two indicator variables: $\mathrm{D}^{\mathrm{m} \& \mathrm{a}}$ equals one in years where statewide branching by mergers and acquisitions were permitted, while $\mathrm{D}^{\text {novo }}$ equals one in years when statewide de novo branching was permitted. Our definitions follow the practice of Jayaratne and Strahan (1996) and Kroszner and Strahan (1999). Deregulation dates are from Amel (1993), Krozner and Strahan (1999), and own updates from individual states' state codes and bills available from the State Legislatures.

Interstate banking restrictions: We measure the direct effect of interstate banking deregulation by an indicator variable, $\mathrm{D}^{\text {inter }}$, which equals one in years where entry by out-of-state bank holding companies were permitted (by mergers and acquisitions). We further define a variable $\mathrm{D}^{\text {reci }}$ which takes into account that most states allowed entry by banks from only neighboring states and on a reciprocal basis. We define $\mathrm{D}^{\text {reci }}$ is the fraction of (outside) states in the sample from which entry is de facto allowed, taking into account whether the reciprocity constraint for each individual outside state is binding or not. The variable, hence, takes fractional values between zero and one, where the value of one means that banks from any other state are able to enter, and the value zero means that banks from no other states are able to enter. ${ }^{31}$ Information on deregulation dates and reciprocity rules, is available from Amel (1993) and own updates from individual states' state codes and bills available from the State Legislatures.

\footnotetext{
${ }^{30}$ Interstate smoothing of earnings can occur through commuting across state borders. The BEA takes into account commuters' income in the construction of personal income data. Therefore, our measure incorporates this kind of interstate income insurance. Similar holds for distributed profits, interest, and rent, which occurs when residents of one state hold securities of corporations and property in other states.

${ }^{31}$ For example, Maine allows national reciprocal entry in 1978, but no other states allow entry, hence, de facto, no out-of-state banks are allowed entry. In 1982, New York allows reciprocal entry and Alaska allows national non-reciprocal entry. Hence, New York and Maine de facto allows entry from only two outside states, whereas Alaska allows entry from 49 outside states. If reciprocal entry is permitted from specific states only, we count whether the reciprocity constraint binds for each individual state and $\mathrm{D}^{\text {reci }}$ equals the number of states with de facto entry divided by the number of states in the sample minus one.
} 
Small Business Employment: We measure the degree of importance of small businesses in a state as the proportion of people employed in small business establishments relative to total employment in 1978, the earliest date available. (Data for the share of small businesses in the population of firms is only available from 1988.) We split states into three equal-sized groups according to this measure ("High," "Low," and "Middle") and say that small businesses are relatively more prevalent in a state if it belongs to the "High" group. By small we mean establishments with a number of employees less than 100. The data is available from Geospatial and Statistical Data Center, University of Virginia library. ${ }^{32}$ Employment is paid employment, which consists of full and part-time employees, including salaried officers and executives of corporations. Included are employees on sick leave, holidays, and vacations; not included are proprietors and partners of unincorporated businesses.

Proprietors' Income: This component of personal income is the current-production income (including income in kind) of sole proprietorships and partnerships and of tax-exempt cooperatives. Corporate directors' fees and the imputed net rental income of owner-occupants of farm dwellings are included in proprietors' income, but the imputed net rental income of owner-occupants of non-farm dwellings is included in rental income of persons. Proprietors' income excludes dividends and monetary interest received by nonfinancial business and rental incomes received by persons not primarily engaged in the real estate business; these incomes are included in dividends, net interest, and rental income of persons, respectively. Data is available from the BEA.

Cumulative Mortgage Backed Securities: Mortgage backed securities are net issues of federally related mortgage pool securities by the Government National Mortgage Association, Fannie Mae, Freddie Mac, and the Farm Service Agency. Data is from the Flows of Funds Accounts of the United States ("Agency-and GSE-Backed Mortgage Pools," Table F.210). Lending Technology: We define a measure, TECH, of banks' use of hard information, namely the value of bank loans per employee by state similar to Petersen and Rajan (2002). The data is from call reports.

\section{Measuring income insurance}

We measure the degree to which personal income is insured between U.S. states. Our measure builds on the method of estimating of risk sharing though capital markets developed by Asdrubali et al. (1996). The following set of assumptions have become standard in

\footnotetext{
${ }^{32}$ See http://fisher.lib.virginia.edu/collections/stats/cbp/state.html
} 
the risk sharing literature: a representative consumer of each region maximizes life-time expected utility from consumption. If utility functions are of the Constant Relative Risk Aversion variety and all regions have a common intertemporal discount factor, the optimal risk sharing allocation satisfies $C_{i t}=k_{i} C_{t}$ for all $t$ and all realizations of uncertainty, where $C_{i t}$ and $C_{t}$ denotes state-level and aggregate consumption, respectively. The constant $k_{i}$ is independent of time and state of the world and reflects the relative value of state $i$ 's endowment stream including initial wealth.

Because our focus is the interconnection of small business owners' personal finances with those of their firms, we focus on income insurance (smoothing). If full risk sharing is achieved via income smoothing, then $I N C_{i t}=k_{i} I N C_{t}$ where $I N C_{i t}$ and $I N C_{t}$ denotes state and aggregate personal income per capita, respectively. If income is fully insured, the income of different states may be at different levels but since the constant $k_{i}$ is independent of time, full income insurance implies that all states have identical growth rates of income. This implication forms the basis of our empirical estimations.

Let $\mathrm{PINC}_{i t}$ and $\mathrm{Y}_{i t}$ denote the growth rates of state personal income and GSP, respectively. Under full income insurance all states have the same growth rate of income: $\mathrm{PINC}_{i t}=\mathrm{PINC}_{j t}$ for all states $i$ and $j$ at all dates $t$. Equivalently, $\operatorname{PINC}_{i t}-\overline{\mathrm{PINC}}_{. t}=0$ where $\overline{\mathrm{PINC}}_{. t}$ is the average across all states in period $t$. The interpretation is that average income growth cannot be insured through cross-state income diversification while $\mathrm{Y}_{i t}-\overline{\mathrm{Y}}_{. t}$, the "idiosyncratic" component of output, can be fully insured. ${ }^{33}$ We also refer to $\left(\mathrm{Y}_{i t}-\overline{\mathrm{Y}}_{. t}\right)$ and $\left(\mathrm{PINC}_{i t}-\overline{\mathrm{PINC}}_{. t}\right)$ as state-specific output and state-specific personal income, respectively.

We prefer our measure of risk sharing to be robust to long lasting differences in income and output growth. States with high immigration of retirees, such as Florida, may well see income growing faster than output when retirees - who don't produce output but receive income - move in. We, therefore, consider output and income in state $i$ adjusted for statespecific means; i.e., we study how much $\widetilde{\mathrm{PINC}}_{i t}=\mathrm{PINC}_{i t}-\overline{\mathrm{PINC}}_{. t}-\overline{\mathrm{PINC}}_{i}$. co-varies with $\widetilde{\mathrm{Y}}_{i t}=\mathrm{Y}_{i t}-\overline{\mathrm{Y}}_{. t}-\overline{\mathrm{Y}}_{i .}$, where for any variable $\mathrm{X}_{i t}$ we define $\overline{\mathrm{X}}_{i .}=\frac{1}{T} \Sigma_{t=1}^{T} \mathrm{X}_{i t}$ where $T$ is the number of years in our sample and $\overline{\mathrm{X}}_{. t}=\frac{1}{N} \sum_{i=1}^{N} \mathrm{x}_{i t}$ where $N$ is the number of states in our sample.

Rather than testing if risk sharing is perfect, we define a measure of income insurance that takes the value zero if income moves one-to-one with output ("no income insurance"); i.e., if $\widetilde{\mathrm{PINC}}_{i t}=\widetilde{\mathrm{Y}}_{i t}$, and the value one if income does not co-move with output ("full income insurance"). More precisely, we measure the amount of income insurance by the estimated

\footnotetext{
${ }^{33}$ We could subtract the aggregate rather than the average with very little effect on the results and no change in the interpretation.
} 
coefficient $\beta$ in the panel data regression:

$$
\widetilde{\mathrm{Y}}_{i t}-\widetilde{\mathrm{PINC}}_{i t}=\beta \widetilde{\mathrm{Y}}_{i t}+\epsilon_{i t} \text {. }
$$

$\beta$ declines with the degree of "pass-through" of state-specific output growth to state-specific income and a value of $\beta>0$ implies income insurance. The more positive is $\beta$, the less state-specific income co-moves with state-specific output and we will interpret a value of 1 as perfect income insurance. We multiply the estimated $\beta$-value (and other parameters) by 100 and we, therefore, refer to $\beta$ as the percentage of risk shared.

In order to examine if income insurance changes with banking deregulation, we allow the coefficient that measures the amount of income insurance to vary by state and over time, in other words, we estimate the relation

$$
\widetilde{\mathrm{Y}}_{i t}-\widetilde{\mathrm{PINC}}_{i t}=\mu_{i}+\nu_{t}+\beta_{i t} \widetilde{\mathrm{Y}}_{i t}+\epsilon_{i t},
$$

where

$$
\beta_{i t}=\beta_{0}+\beta_{1} \mathrm{x}_{i t},
$$

and $\mu_{i}$ and $\nu_{t}$ are state- and time-fixed effects (dummy variables), respectively. ${ }^{34}$

In this regression the inclusion of the $\mathrm{x}_{i t}$-term allows the amount of income insurance to vary with the value of $\mathrm{x}_{i t}$. $\beta_{0}$ then measures the average amount of income insurance when $\mathrm{x}_{i t}$ is zero. ${ }^{35}$ We will refer to such $\mathrm{x}_{i t}$-terms as "interaction terms." $\beta_{1}$ measures the increase in income insurance associated with a one unit increase in $\mathrm{x}$ and the focus of much of our work is to examine the size of this coefficient. In particular, if this coefficient is significantly different from zero, it implies that the relevant $\mathrm{X}$-variable has an impact on income insurance. In the following we discuss the detailed implementation for various interaction variables - depending on the specific variable $\mathrm{x}_{i t}$ will be unadjusted, adjusted for its overall mean, or adjusted for the mean state-by-state. We discuss these details next.

Our main interaction terms are dummy variables for various types of banking deregulation. Let $\mathrm{D}_{i t}$ be a generic term which describes one of our three dummy variables for banking deregulation, explained in section 6, which all take the value 0 in state $i$ in the years

\footnotetext{
${ }^{34}$ Equation (1) is written in terms of deviations from state- and time-averages, hence, including fixedeffects will not change the estimated value of $\beta_{0}$. The fixed effects have no impact in equation (2) because the variables are in the form of deviations from time- and state-specific means but they have an impact when interaction terms are included below.

${ }^{35}$ Such regressions were previously used to estimate risk sharing by Melitz and Zumer (1999) and Sørensen, $\mathrm{Wu}$, Yosha, and Zu (2005).
} 
before, and the value 1 after, deregulation. In this case, $\beta_{0}$ measures the amount of income insurance before deregulation and $\beta_{0}+\beta_{1}$ measures the the amount of income insurance after deregulation and $\beta_{1}$ the change in income insurance. For the continuous measure of interstate banking deregulation, $\mathrm{D}^{\text {reci }}, \beta_{1}$ measures the increase in income insurance in a state that goes from a prohibition on out-of-state entry to nationwide entry (that is, when $\mathrm{D}_{i t}^{\text {reci }}$ goes from zero to one).

Several things changed in financial markets over the period we examine. Of particular relevance is the integration of mortgage markets into a nationwide market and technological advances that allowed physical distances between banks and firms to increase. These developments potentially lead to greater risk sharing between states and because these developments partly took place a the same time as banking regulations were relaxed we need to examine if banking integration is still an important explanatory factor when these other competing explanations are taken into account.

Petersen and Rajan (2002) verify that changes in lending technology allow banks to lend at larger distances. The lending technology used by banks is not directly observable and they use as an approximation the measure of lending technology TECH, bank loans per employee, which is basically a proxy for banks' lending efficiency. We examine if TECH helps predict the amount of income insurance that states obtain and, in particular, if our measures of banking deregulation help explain insurance when lending technology is included as an explanatory factor.

We estimate the relation

$$
\beta_{i t}=\beta_{0}+\beta_{1} \mathrm{D}_{i t}+\beta_{2}\left(\mathrm{TECH}_{i t}-\overline{\mathrm{TECH}}_{i .}\right)
$$

where "D" refers to one (or several) of our measures of deregulation. Lending technology is likely to vary between, say, agricultural states and financial center states, and we control for this by subtracting the state-level average. One needs to interpret the results of this regression carefully: deregulation allows for banks to merge into larger organizations that are likely at an advantage in using data-based lending technology because such technologies display economies of scale. Therefore, technological change may be a competing explanation for increased income insurance but it may also be the result of banking deregulation. Nonetheless, it is important to know if banking reform improved risk sharing even after lending technology is taken into account.

The nationwide integration of mortgage markets may well be another reason why risk sharing increased during our sample period and we explore this issue to a limited extent. 
We define MBS to be the total outstanding amount of securitized mortgage assets issued by government sponsored enterprizes divided by GDP. We then perform the risk sharing regression with

$$
\beta_{i t}=\beta_{0}+\beta_{1} \mathrm{x}_{i t}+\beta_{2}\left(\mathrm{MBS}_{t}-\overline{\mathrm{MBS}}\right) .
$$

If $\beta_{2}$ is significant and positive this implies that the securitization of mortgage markets indeed is associated with better income insurance. We do not attempt to identify state-varying impacts from the integration of mortgage markets. This question is highly interesting in its own right but a more detailed study of it would take us too far afield in this paper. ${ }^{36}$

Risk sharing between states may increase over time due to a myriad of underlying economic causes besides the ones just discussed. We, therefore, examine the effect of including a quadratic trend in risk sharing in our estimation. For a relevant variable, $\mathrm{x}$, we specify the coefficient $\beta_{i t}$ as

$$
\beta_{i t}=\beta_{0}+\beta_{1} \mathrm{x}_{i t}+\beta_{2}(t-\bar{t})+\beta_{3}(t-\bar{t})^{2},
$$

where the X-variable is adjusted for it's overall mean or state-specific mean in the same way as in the regressions without trend. We include a quadratic term in time because income insurance cannot grow linearly forever. ${ }^{37}$

In order to test whether banking integration improved income insurance for small business owners, we split our sample of states into three sub-samples according to the fraction of small businesses. We have argued that small businesses are the business units most dependent on bank finance so it is essential for our interpretation that banking deregulation has stronger effects in the group of states where small businesses are most prevalent. ${ }^{38}$

We perform regressions such as equation (1) on each of the three subsamples separately and examine if the impact of banking reform as measured by the $\beta$-coefficient is larger in the subgroup with a high prevalence of small businesses. Note, that in these regressions

\footnotetext{
${ }^{36}$ As a technical matter, we deduct the mean value of MBS because this keeps the interpretation of $\beta_{0}$ unchanged. When MBS is not included in the regression, $\beta_{0}$ measures (approximately) the amount of risk sharing when MBS takes its average value. In a regression where MBS is included and $\overline{\mathrm{MBS}}$ is not subtracted from MBS, the interpretation of $\beta_{0}$ is the amount of risk sharing when mBS $=0$. Typically, if $\hat{\beta}_{0}$ is the estimate of $\beta_{0}$ from the former regression and $\tilde{\beta}_{0}$ is the estimate from the latter regression, one would find $\tilde{\beta}_{0}=\hat{\beta}_{0}-\hat{\beta}_{2} \overline{\mathrm{MBS}}$ while the estimated value of $\beta_{0}$ would be about invariant when the average has been subtracted from MBS as in our implementation. The estimated value of $\beta_{2}$ is mathematically identical in the two regressions. Braumoeller (2004) gives an elementary treatment of this issue with examples.

${ }^{37} \mathrm{We}$ do not restrict the estimated value of $\beta$ to be less than one, but a value larger than one implies that income drops when output increases and vice versa which is unlikely to be a typical situation.

${ }^{38} \mathrm{As}$ a robustness check we alternatively measured the importance of small businesses by the number of small firms in 1988 (the earliest available year). The results using this measure are very similar and we, therefore, do not tabulate them.
} 
the definitions of $\tilde{Y}$ and $\widetilde{P I N C}$ are the same as in the earlier regressions; i.e., we remove the average across all states - the interpretation, therefore, is that we measure the amount of risk sharing relative to the benchmark of full U.S.-wide risk sharing. (Had we controlled only for the averages in each sub-group we would be measuring the amount of risk sharing within the sub-group and not the amount of risk they share with all U.S. states.)

\section{$7.1 \quad$ Econometric issues}

We implement the relation described by equations (2) and (3) by estimating the relation

$$
\widetilde{\mathrm{Y}}_{i t}-\widetilde{\mathrm{PINC}}_{i t}=\mu_{i}+\nu_{t}+\beta_{0} \widetilde{\mathrm{Y}}_{i t}+\beta_{1} \mathrm{X}_{i t} \widetilde{\mathrm{Y}}_{i t}+\gamma \mathrm{X}_{i t}+\epsilon_{i t},
$$

using Generalized Least Squares (GLS). We interpret $\beta_{0}+\beta_{1} \mathrm{x}_{i t}$ as the time-varying risk sharing coefficient $\beta_{i t}$. The "linear term" $\gamma \mathrm{x}$ shows whether the variable $\mathrm{x}$ had an impact on that the average growth difference between income and output - this is not of interest in the present study, but we include the term, as it is normally done in regressions allowing for interaction effects, in order to ascertain that the estimated coefficient to the interaction term would not be affected by erroneously leaving out a significant linear term.

Our estimations utilize a two-step GLS-estimator. The first step is a panel Ordinary Least Squares (OLS) estimation. From the residuals we estimate the variance of the error terms in the regression assuming that it varies by state - the estimates typically confirm this assumption with small states having higher residual variance than large states. In the second step the variables for each state are weighted by the estimated standard error for the state. It is feasible that the error terms may be correlated over time within each state and correlated with state-specific output growth (the regressor). Bertrand, Duflo, and Mullinaithan (2004) demonstrate that such "clustering" of standard errors can lead to severely biased estimated standard errors in the presence of serial correlation. Our data does not display severe autocorrelation but we find it prudent to guide against biased inference by displaying estimated standard errors that are robust to "clustering-type" heteroskedasticity. ${ }^{39}$

We also display our cental results using simple OLS regressions, which tend to give relatively larger weights (unity) to small states. The OLS regressions are less statistically efficient and serve to establish if the results are robust.

\footnotetext{
${ }^{39}$ Our implementation is similar to the robust clustering procedure built into the STATA econometrics package.
} 


\subsection{Proprietors' income}

Proprietors are typically dependent on banks to the same degree as small business owners and we would also like to examine if banking reform lead to disproportionately higher income insurance for proprietors. We do not directly observe the production output from proprietors and we, therefore, cannot directly estimate the amount of income insurance obtained by proprietors. However, we can examine if proprietors' income has become less sensitive to output growth following banking reform. We estimate the amount of proprietors' income "smoothing" from the regression

$$
\operatorname{PROPINC}_{i t}=\mu_{i}+\nu_{t}+\beta_{0} \widetilde{\mathrm{Y}}_{i t}+\beta_{1} \mathrm{D}_{i t} \widetilde{\mathrm{Y}}_{i t}+\gamma \mathrm{D}_{i t}+\epsilon_{i t},
$$

where PROPINC $i t$ measures aggregate proprietors' income in state $i$ in period $t$ and $\mathrm{D}$ is one (or several) of our measures of deregulation. Here, a positive value of $\beta_{0}$ implies that proprietors' income co-moves with output and a value larger than 100 percent implies that a given percentage shock to state-level output is associated with a more than 100 percent change in proprietors' income in the same direction. A negative value of $\beta_{1}$ indicates that an increase in the D variable typically is associated with less sensitivity of proprietors' income to output shocks. We consider the negative of the estimated value of $\beta_{1}$ a proxy for the measured effect on small business owners' income insurance. For completeness, we also examine if wage income and dividend, interest, and rental income have become less sensitive to output growth following deregulation.

\section{Results and discussion}

\subsection{Descriptive Figures and Tables}

Figure 1 displays a graph of the average value of $D^{\text {reci }}$ across states for each year in our sample and, similarly, the value $\mathrm{D}^{\text {reci }}$ over time for 3 randomly selected states. For Idaho the variable looks much like a dummy variable while for Michigan and New York, the variable gradually increase from 0 to 1 during the period from the early 1980s to the mid-1990s.

Figure 2 displays the growth rates of GSP and personal income for the average U.S. state and the state-specific (state minus average) growth rates of GSP and personal income for Idaho, Michigan, and New York. It appears that volatility of state-level GSP declined after deregulation as documented by Morgan et al. (2004) (Panel A). Panels B-D show that large fluctuations in state-specific GSP are typically associated with large fluctuations in personal 
income, but the latter are damped relative to those of GSP, reflecting interstate income insurance. We mark the dates of the three discrete banking deregulations by vertical lines and we display the correlation of state-specific income with state-specific GSP before and after deregulation. For the displayed states the correlation of personal income with GSP declined after each type of deregulation.

Figure 3 shows similar graphs with proprietors' income instead of personal income. The volatility of proprietors' income has declined considerably since the early 1980s where proprietors' income displayed extremely high sensitivity to GSP-shocks. During that period fluctuations in GSP were strongly amplified in proprietors' income (Panel A). For the three selected states we observe a strong decline in the amplitude of state-specific proprietors' income in the period after banking reform. While changes in GSP are not equivalent to "endowment shocks" for proprietors, this pattern is nevertheless consistent with better income insurance for proprietors following banking deregulation.

Table 2 displays the average values, standard deviations and correlations for our deregulation variables. The mean value of the dummy variables has a simple interpretation as the fraction of the sample for which the particular form of deregulation has been in place. For example, on average states had removed restrictions on intrastate branching by mergers and acquisitions for 60 percent of the years in our sample.

The correlation matrix shows that all our integration measures are positively correlated, in particular, the pair of intrastate deregulation variables and the pair of interstate deregulation variables are highly correlated; 0.82 and 0.79 respectively. This makes it difficult to estimate the separate impact of the variables in a regression that includes both intrastate (or both interstate) deregulation measures. The correlations between each of the intrastate dummies with each of the interstate deregulation variables are above 0.5 but no higher than 0.64. Out data set is fairly large, hence a correlation of this magnitude may potentially, but not necessarily, be too high to for us to separate the impact of intrastate from interstate deregulation. The measure of lending technology is quite highly correlated with the interstate deregulation dummies, with correlations of around 0.6 , but less correlated with the measures of intrastate deregulation.

\subsection{Bank reform and income insurance}

Did interstate income insurance increase following banking reform? In Table 3 we examine whether risk sharing improved following deregulation. In the top part of the table, we display results for each deregulation measure separately, for all measures together, and 
for combinations of measures, in order to establish which of the variables capture the effect of deregulation best. At the bottom part of Table 3 we display the coefficients to the deregulation variables in non-interacted form. The coefficient estimates of the noninteracted terms show whether output in deregulated states tend to grow faster than income. This question is not of interest for the purposes of our study and the variables are included as a control variables - we suppress the non-interacted coefficients in the following tables (but continue to include them in the regressions).

The first four columns of Table 3 show that each banking deregulation variable strongly and significantly predicts higher income insurance. In particular, income insurance was, on average, 45 percent before deregulation of restrictions on branching by mergers and acquisitions, confer the coefficient on GSP in column (1). This estimate is large in economic terms and strongly significant. ${ }^{40}$ After deregulation, the amount of income insurance increased to $55.3(45.0+10.3)$ percent. The estimated impact (10.3) of banking deregulation is large in economic terms and the estimate is statistically significant at the usual five percent level. The results in columns (2) and (3) are of similar magnitude, while the estimated impact of interstate deregulation, as measured by $\mathrm{D}^{\text {reci }}$, is even larger with an increase in risk sharing of almost 18 percent.

In column (5) we include all four measures of deregulation. The estimated impact of $\mathrm{D}^{\text {reci }}$ is about unchanged, but the estimated impact of $\mathrm{D}^{\text {novo }}$ and interstate deregulation $\mathrm{D}^{\text {inter }}$ are now both negative. Clearly, the deregulation variables are so highly correlated that we cannot sort out the relative effect of each variable. Next, in column (6) we ask a less ambitious question: which of the two intrastate deregulation variables have the highest explanatory power, and similarly for the pair of interstate deregulation measures, column (7). Considering intrastate branching deregulation first: branching by mergers and acquisitions appears more important than de novo branching. Of the interstate deregulation measures, clearly $\mathrm{D}^{\mathrm{reci}}$ is the most important. In columns (8) and (9) we run regressions with combinations of intrastate and interstate deregulation measures. We first combine the measures from each deregulation group, $\mathrm{D}^{\mathrm{m} \& \mathrm{a}}$ and $\mathrm{D}^{\text {reci }}$, that had the higher significance in the previous columns. We find that the interstate measure has very high statistical significance while the intrastate measure is not significant, although the estimated coefficient is positive and of a reasonable size. When we, alternatively, use the combination of $\mathrm{D}^{\text {novo }}$

\footnotetext{
${ }^{40}$ The estimate is very close to the 39 percent value for "capital market risk sharing" found by Asdrubali et al. (1996). They defined "capital market" risk sharing similarly to our measure of income insurance except that they removed all federal transfers to persons from personal income but added all revenue of state governments, not collected from individuals in the state. Nonetheless, their estimate has a very similar interpretation to ours.
} 
and $\mathrm{D}^{\text {inter }}$, we obtain similar results, as $\mathrm{D}^{\text {inter }}$ is highly significant and the impact of $\mathrm{D}^{\text {novo }}$ is positive although not statistically significant at conventional levels. In the following, we run regressions of the type shown in columns (8) and (9) in order to examine whether intrastate or interstate deregulations had the larger impact on income insurance.

Overall, the results of Table 3 clearly indicate that income insurance improved markedly after deregulation and, while intrastate and interstate deregulation both appear to matter, it seems that the strongest effects comes from interstate deregulation. In the following we examine whether the inclusion of other potential determinants of risk sharing may explain these results, and whether the result are robust to reasonable changes in the sample and the estimation procedure. We first, however, move on to ask whether banking deregulation had a relatively larger impact in states with many small businesses as theory would suggest.

\subsection{Banking reform and small businesses}

In Table 4, we estimate the relation between income insurance and banking reform separately for the third of the states with the highest fraction of employees in small businesses, the third with the lowest fraction, and the middle third. We expect to find a higher effect of deregulation in states with a high number of small businesses and this result is brought out very clearly by the results of Table 4 . We display $t$-statistics for the null hypothesis that the group of states with many small businesses is similar to the remaining states. We reject this hypothesis at the ten percent level of significance for $\mathrm{D}^{\text {reci }}$ and at the fiver percent level or better for the other deregulation variables.

One may notice the large coefficient estimate for $\mathrm{D}^{\text {reci }}$ in the group of states with fewer small businesses and, to a lesser extent, for $\mathrm{D}^{\text {inter }}$. Both measures predict a somewhat higher effect of deregulation in states with many small businesses, but the coefficient estimates for the "low" group suggest that interstate deregulation is associated with improvements in income insurance that do not work predominantly through small businesses. In contrast, the effects of intrastate deregulations are mainly relevant for small businesses. These results are consistent with our hypothesis that a banking system comprised of small banks shielded from competition are prone to inefficiencies stemming from lack of diversification, scale economies, little integration into national credit and capital markets, etc. Our results suggest that these inefficiencies are detrimental for bank-dependent small firms and the welfare of small business owners. The results are also consistent with the finding of Jayaratne and Strahan (1996) that improvements in bank efficiency are behind the sizeable growth-effects of intrastate deregulation that they estimate. 
The difference between the estimated effects of the intrastate and interstate variables indicates that the main issue for small businesses is whether banks branch and merge and less whether banks become part of cross-border organizations. We conjecture that the interstate deregulation measures are picking up fewer of the effects from consolidation and more of the effect from improved risk sharing between banks - effects that are likely to benefit not only small business owners.

Also notice that the estimated level of income insurance before deregulation (row "GSP") is lower in states with a high prevalence of small businesses. This is consistent with our hypothesis that it is relatively harder for small business owners to smooth their income due to the intertwining of their personal income with that of their business.

Table 5 shows the results from multivariate regressions including both intrastate and interstate deregulation variables as regressors. The results are very similar to those in Table 4. We find that the authorization of branching by mergers and acquisitions had a strong effect on risk sharing in states with many small businesses but no significant effect in other states, while interstate deregulation as measured by $D^{\text {reci }}$ had an equally strong effect in states with many and few small businesses. The results are robust to which particular pair of intra- and interstate deregulation dummies we use, except the estimated impact of $\mathrm{D}^{\text {inter }}$ is smaller than the estimated impact of $\mathrm{D}^{\text {reci }}$.

\subsection{The impact of banking reform versus the impact of lending technol- ogy and integration of mortgage markets}

The increase in income insurance that occurred after deregulation is not necessarily a unique result of banking reform. In this sub-section we examine if banking deregulation is still a significant predictor of income insurance when we simultaneously allow for either a measure of lending technology or a measure of national mortgage market integration.

Banking deregulation happened at about the same time as improvement in technology made it possible to lend at larger distances. We, therefore, in Table 6, add a measure of the efficiency of lending technology in banking, TECH, to the regressions that estimate the effect of deregulation for the full sample of states. The first column of Table 6 shows that lending technology is a significant predictor of income insurance. However, when we include either pair of bank deregulation measures, deregulation remains significant while lending technology becomes insignificant. The point estimate for lending technology is even negative, which is likely a reflection of too high correlation with the banking deregulation variables. 
Alternatively, when we include a measure of mortgage market integration, MBs, which does not vary by state, the coefficient is clearly significant, confer column (4). The estimated impact of mortgage market integration is not robust to inclusion of the banking deregulation variables: in column (5), where the $\mathrm{D}^{\mathrm{m} \& \mathrm{a}}$ and $\mathrm{D}^{\text {reci }}$ variables are included, the measure of mortgage market integration is insignificant while the point estimate for $\mathrm{D}^{\text {reci }}$ is very close to that found in Table 3, although the estimate now is only borderline significant at the five percent level due to a higher standard deviation. Using the $\mathrm{D}^{\text {novo }}$ and $\mathrm{D}^{\text {inter }}$ measures, MBS becomes larger and near significant, while the banking deregulation variables become smaller and statistically insignificant.

Our results suggest that it is difficult to separate the effect of banking deregulation from other trending variables. During our sample period, states' status change from regulated to deregulated, and no state moves in the opposite direction. Therefore, our bank integration measures are correlated with a trend and we examine how robust the results are to the inclusion of a quadratic trend.

Including the trend in Table 7, we see from columns (1)-(4) that the estimated coefficients of the intrastate deregulation variables remain positive but become insignificant, while $\mathrm{D}^{\text {inter }}$ turns negative, and $\mathrm{D}^{\text {reci }}$ retains its order of magnitude and remains significant. Including both intrastate and an interstate deregulation variables do not change the results much.

The trend in risk sharing is a function of underlying changes in the economy and deregulation itself is likely to be a partial explanation for this trend. The results so far, however, leave open doubt about the importance of banking deregulation amidst the other potential explanations. If intrastate banking deregulation is important we should see a stronger impact where small business are more prevalent, even in the presence of a trend, and we turn to that question next.

Table 8 shows that intrastate branching deregulation had a strong positive effect in states with many small businesses. The result is robust to trend and the effect of branching deregulation is significantly larger than in other states. The estimated impact of deregulation is negative in the two other groups of states, even significantly so for states with few small businesses in the case of $\mathrm{D}^{\mathrm{m} \& \mathrm{a}}$. The negative coefficient estimate is due to the correlation with the trend. The important finding is that the intrastate deregulation variables have disproportionately larger impacts in states with many small businesses and this results is clearly statistically significant with a $t$-value of 2.6 for each of the intrastate deregulation variables. As found in Table 4, the interstate branching variables do not have significantly different impacts in states with many or few small businesses. The point estimates for the 
interstate variables seem noisy in this table, but the overall message is that the impact of intrastate deregulation on income insurance, in states with many small businesses, is robust to the inclusion of trend.

\subsection{Banking deregulation and the sensitivity of proprietors' income and other income categories to GSP-fluctuations}

A different way of examining if risk sharing increased after banking reform is to consider if proprietors' income became less correlated with state-specific output shocks following banking reform. In Table 9 we show the results of regressions of proprietors income on output shocks allowing for fixed effects and interactions with deregulations variables. We interpret the results as reflecting risk sharing although state-level output is not a direct endowment shock for proprietors; nonetheless, a lower co-movement of proprietors income with output following banking deregulation is likely to, at least partly, reflect increased income insurance. The coefficient on GSP in column (1) of of Table 9 shows that before banking reform a one percent drop in state-specific output would on average be associated with a 2.88 percent drop in proprietors' income, that is, state-specific proprietors' income is more volatile than output. The predicted impact after "full" banking deregulation (where both $\mathrm{D}^{\mathrm{m} \& \mathrm{a}}$ and $\mathrm{D}^{\text {reci }}$ are equal to unity) is that a one percentage point fall in state-specific output is associated with only a 0.1 percent drop in proprietors' income (288.4-204.0-65.8 percent of one percent). The estimates have large standard errors but both $\mathrm{D}^{\mathrm{m} \& \mathrm{a}}$ and $\mathrm{D}^{\text {reci }}$ are significant at the conventional five percent level. The results are similar using the alternative set of banking deregulation variables in column (2). The high level of significance of the measures of banking deregulation is unaffected by inclusion of a quadratic trend. In columns (5) and (6) we examine if wage-growth became less correlated with output shocks following deregulation. The point estimates imply that intrastate banking deregulation increased the correlation of wages with output shocks while interstate deregulation lowered the correlation by a similar amount, implying a zero overall effect. We do not further attempt to solve this somewhat puzzling result because the impact on wage smoothing is not our focus here. There is no significant impact of banking deregulation on the sensitivity of interest, dividend, and rental income to output shocks, confer columns (7) and (8). This result is intuitive because such income to a large extent is diversified across the United States. 


\subsection{Robustness}

We, next, consider the robustness of our results: we examine whether the results are unchanged if the small more volatile oil states, Alaska and Wyoming, are dropped from the sample; and we examine whether the results are similar when we use OLS, rather than GLS, estimation-OLS estimation, being un-weighted, is likely to give larger weight to smaller states. Table 10 displays the estimated impact of banking deregulation in the case with and without a quadratic trend for the case where Alaska and Wyoming are omitted from the sample. The results are similar to those obtained with Alaska and Wyoming, except that all banking deregulation variables are insignificant when a quadratic trend is included. However, Table 11 shows that our main result, that intrastate banking deregulation had a disproportionately large and positive effect on risk sharing in states with many small businesses, still holds whether is a trend is included or not. In fact, the statistical nullhypothesis that states with many small businesses obtain no more risk sharing than other states is rejected with even higher levels of significance when Alaska and Wyoming are left out.

Table 12 reveals that our results for the sensitivity of proprietors' income to output shocks are quite robust to the exclusions of Alaska and Wyoming, although the statistical significance of the coefficients are slightly lower. Similarly for wage and dividend, rental, and interest income. However, all of regressions involving proprietors' income have at least one deregulation variable significant at the five percent level.

Table 13 displays the results when OLS estimation is used. The estimated coefficients are all very large and highly significant, with the exception of $D^{\text {inter }}$ when a quadratic trend is included. The point estimates are somewhat high, implying that moving from no deregulation to full intrastate and interstate deregulation improves income insurance by about 40 percentage points, which is likely a reflection of the higher weight given to smaller states in the sample with OLS.

Finally, Table 14 shows that the finding that intrastate banking deregulation had a stronger impact in states with many small businesses is robust to OLS-estimation. The overall pattern of the results are very similar under GLS and OLS-estimation and the estimated differential impact in states with more or less small businesses is even stronger when OLS is used. We consider the OLS-estimates more noisy than the GLS-estimates but, clearly, our conclusions hold up using this simple estimator. 


\section{Conclusion}

This paper provides evidence that U. S. banking deregulation and the consequent changes in bank market structure had significant real effects on the economy through the role played by banks as the main source of funds for small businesses.

In particular, we demonstrate that interstate risk sharing at the income level (income insurance) increased significantly in states which deregulated restrictions on banks' ability to operate branching networks or holding companies within or between states. We hypothesize that an important channel for this effect goes through small businesses because of the intertwining of the personal finances of bank-dependent small business owners with the finances of their firms. We find two sets of results consistent with this hypothesis. First, we show that the positive effect of deregulation on income insurance is significantly stronger in states where small businesses are more important, measured in terms of share of employment. Second, we show that proprietors' income is considerably less sensitive to output shocks following banking deregulation. We conjecture that the changes in the U.S. banking industry that have lead to an improvement in income insurance are due to improved efficiency in lending to small businesses after deregulation and to improved efficiency of interbank capital allocation. 


\section{References}

Agronin, Eugene, 2003, Risk-sharing across the United States, proprietary income, and the business cycle, Manuscript, Harvard University .

Allen, Franklin, and Douglas Gale, 2000, Comparing financial systems (MIT Press, Cambridge and London).

Amel, Dean, 1993, State laws affecting the geographic expansion of commercial banks, Manuscript, Board of Governors of the Federal Reserve System .

Amel, Dean F., and J. Nellie Liang, 1992, The relationship between entry into banking markets and changes in legal restrictions on entry, The Antitrust Bulletin Fall, 631649 .

Ang, James S., 1992, On the theory of finance for privately held firms, Journal of Small Business Finance 1, 185-203.

Asdrubali, Pierfederico, Bent E. Sørensen, and Oved Yosha, 1996, Channels of interstate risk sharing: United States 1963-1990, Quarterly Journal of Economics 111, 10811110 .

Ashcraft, Adam, 2001, New evidence on the lending channel, forthcoming in the Journal of Money Credit and Banking .

Atkeson, A., and T. Bayoumi, 1993, Do private capital markets insure regional risk? Evidence from the United States and Europe, Open Economics Review IV, 303-324.

Avery, Robert B., Raphael W. Bostic, and Kathrine A. Samolyk, 1999, The role of personal wealth in small business finance, Journal of Banking and Finance 22, 1019-1061.

Berger, Allen N., Seth D. Bonime, Lawrence Goldberg, and Lawrence J. White, 1999, The dynamics of market entry: The effects of mergers and acquisitions on de novo entry in banking., Proceedings of the 35th annual Conference on Bank Structure and Competition .

Berger, Allen N., Nathan H. Miller, Mitchell A. Petersen, Raghuram G. Rajan, and Jeremy C. Stein, 2005, Does function follow organizational form? Evidence from the lending practices of large and small banks, Journal of Financial Economics 76, $237-269$. 
Berger, Allen N., and Gregory F. Udell, 1998, The economics of small business finance: The roles of private equity and debt markets in the financial growth cycle, Journal of Banking and Finance 22, 613-673.

Bertrand, Marianne, Esther Duflo, and Sendhil Mullinaithan, 2004, How much should we trust difference-in-differences estimators?, Quarterly Journal of Economics 119, 249276 .

Besanko, David, and Anjan V. Thakor, 1987, Collateral and rationing: Sorting equilibria in monopolistic and competitive credit markets, International Economic Review 28, $671-689$.

Bester, Helmut, 1985, Screening vs. rationing in credit markets with imperfect information, American Economic Review 75, 850-855.

Black, Sandra E., and Philip E. Strahan, 2002, Entrepreneurship and bank credit availability, Journal of Finance 57, 2807-2833.

Boot, Arnoud W. A., 2000, Relationship banking: What do we know?, Journal of Financial Intermediation 9, 7-25.

Boot, Arnoud W. A., and Anjan V. Thakor, 2000, Can relationship banking survive competition?, Journal of Finance 55, 679-713.

Braumoeller, Bear F., 2004, Hypothesis testing and multiplicative interaction terms, International Organization 58.

Crucini, Mario J., 1999, International and national dimensions of risk sharing, Review of Economics and Statistics 81, 73-84.

Demsetz, Rebecca S., and Philip E. Strahan, 1997, Diversification, size, and risk at bank holding companies, Journal of Money, Credit and Banking 29, 300-313.

DeYoung, Robert, 1998, Comment on: De novo banks and lending to small businesses: An empirical analysis, Journal of Banking and Finance 22, 868-872.

Dick, Astrid A., 2003, Nationwide branching and its impact on market structure, quality and bank performance, forthcoming in the Journal of Business .

Franks, Julian R., and Oren Sussman, 2005, Financial distress and bank restructuring of small to medium size U.K. companies, Review of Finance 9, 65-96. 
Goldberg, Lawrence G., and Lawrence J. White, 1998, De novo banks and lending to small businesses: An empirical analysis, Journal of Banking and Finance 22, 851-867.

Heuson, Andrea J., Wayne Passmore, and Roger Sparks, 2001, Credit scoring and mortgage securitization: Implications for mortgage rates and credit availability, Journal of Real Estate Finance and Economics 23, 337-63.

Holmstrom, Bengt, and Jean Tirole, 1997, Financial intermediation, loanable funds, and the real sector, Quarterly Journal of Economics 112, 663-691.

Houston, Joel F., and Christopher James, 1998, Do bank internal capital markets promote lending?, Journal of Banking and Finance 22, 899-918.

Houston, Joel F., Christopher James, and D. Marcus, 1997, Capital market frictions and the role of internal capital markets in banking, Journal of Financial Economics 46, $135-164$.

Jayaratne, Jith, and Philip E. Strahan, 1996, The finance-growth nexus: Evidence from bank branch deregulation, Quarterly Journal of Economics 111, 639-670.

Jayaratne, Jith, and Philip E. Strahan, 1998, Entry restrictions, industry evolution and dynamic inefficiency: Evidence from commercial banking, Journal of Law and Economics 49, 239-274.

Kashyap, Anil K., and Jeremy C. Stein, 2000, What do a million observations on banks say about the transmission of monetary policy?, American Economic Review 90, 407-428.

Kolari, James W., Donald R. Fraser, and Ali Anari, 1998, The effect of securitization on mortgage marketk yields: A cointegration analysis, Journal of Real Estate Economics 26, 677-693.

Kroszner, Randall, and Philip E. Strahan, 1999, What drives deregulation? Economics and politics of relaxation of bank branching restrictions, Quarterly Journal of Economics 114, 1437-1467.

Leland, Hayne E., and David H. Pyle, 1977, Informational asymmetries, financial structure, and financial intermediation, Journal of Finance 32, 371-387.

McLaughlin, Susan, 1995, The impact of interstate banking and branching reform: Evidence from the States, Current Issues in Economics and Finance. Federal Reserve Bank of New York 1, 1-6. 
Melitz, Jacques, and Frdric Zumer, 1999, Interregional and international consumption risk sharing and lessons for EMU, Carnegie-Rochester Conference Series on Public Policy $51,149-188$.

Morgan, Donald P., Bertrand Rime, and Philip E. Strahan, 2004, Bank integration and state business cycles, Quarterly Journal of Economics 119, 1555-1584.

Ostergaard, Charlotte, 2001, External financing costs and banks' loan supply: Does the structure of the bank sector matter?, Manuscript, Norwegian School of Management .

Peek, Joe, and Eric S. Rosengren, 1998, Bank consolidation and small business lending: It's not just bank size that matters, Journal of Banking and Finance 122, 799-819.

Pennacchi, George G., 1988, Loan sales and the cost of bank capital, Journal of Finance $43,375-396$.

Petersen, Mitchell A., and Raghuram G. Rajan, 1994, The benefits of lending relationships: Evidence from small business data, Journal of Finance 49, 3-37.

Petersen, Mitchell A., and Raghuram G. Rajan, 1995, The effects of credit market competition on lending relationships, Quarterly Journal of Economics 110, 407-443.

Petersen, Mitchell A., and Raghuram G. Rajan, 2002, Does distance still matter? The information revolution in small business lending, Journal of Finance 57, 2533-2570.

Rajan, Raghuram G., 1992, Insiders and outsiders: The choice between informed and arm's-length debt, Journal of Finance 47, 1367-1400.

Sala-i Martin, Xavier, and Jeffrey Sachs, 1992, Fiscal federalism and optimum currency areas: Evidence for Europe from the United States, in P. Masson M. Canzoneri and V. Grilli, (eds.) Establishing a Central Bank: Lessons in Europe and Lessons from the U.S. (Cambridge University Press, London, U.K.).

Sharpe, Steven A., 1990, Asymmetric information, benk lending, and implicit contracts: A stylized model of customer relationships, Journal of Finance 35, 1069-1087.

Sørensen, Bent E., Yi-Tsung Wu, Oved Yosha, and Yu Zu, 2005, Home bias and international risk sharing: Twin puzzles separated at birth, Manuscript, University of Houston 
Strahan, Philip E., and James P. Weston, 1998, Small business lending and the changing structure of the banking industry, Journal of Banking and Finance 122, 821-845.

Wirtz, Ronald A., 2005, Community banks full of change, fedgazette, federal reserve bank of minneapolis January.

Wolken, John D., 1998, "New" data sources for research on small business finance, Journal of Banking and Finance 22, 1067-1076. 
Table 1:

Year of Banking Deregulation

\begin{tabular}{|c|c|c|c|}
\hline States & $\begin{array}{c}\text { Statewide } \\
\text { branching through } \\
\text { M\&As permitted }\end{array}$ & $\begin{array}{l}\text { Interstate } \\
\text { banking } \\
\text { permitted }\end{array}$ & $\begin{array}{c}\text { Statewide } \\
\text { de novo branching } \\
\text { permitted }\end{array}$ \\
\hline Alabama & 1981 & 1987 & 1990 \\
\hline Alaska & 1960 & 1982 & 1960 \\
\hline Arizona & 1960 & 1986 & 1960 \\
\hline Arkansas & 1994 & 1989 & 1999 \\
\hline California & 1960 & 1987 & 1960 \\
\hline Colorado & 1991 & 1988 & 1997 \\
\hline Connecticut & 1980 & 1983 & 1988 \\
\hline Delaware & 1960 & 1988 & 1960 \\
\hline District of Columbia & 1960 & 1985 & 1960 \\
\hline Florida & 1988 & 1985 & 1988 \\
\hline Georgia & 1983 & 1985 & 1998 \\
\hline Hawaii & 1986 & 1995 & 1986 \\
\hline Idaho & 1960 & 1985 & 1960 \\
\hline Illinois & 1988 & 1986 & 1993 \\
\hline Indiana & 1989 & 1986 & 1991 \\
\hline Iowa & 1997 & 1991 & $* * *$ \\
\hline Kansas & 1987 & 1992 & 1990 \\
\hline Kentucky & 1990 & 1984 & 2001 \\
\hline Louisiana & 1988 & 1987 & 1988 \\
\hline Maine & 1975 & 1978 & 1975 \\
\hline Maryland & 1960 & 1985 & 1960 \\
\hline Massachusetts & 1984 & 1983 & 1984 \\
\hline Michigan & 1987 & 1986 & 1988 \\
\hline Minnesota & 1993 & 1986 & $* * *$ \\
\hline Mississippi & 1986 & 1988 & 1989 \\
\hline Missouri & 1990 & 1986 & 1990 \\
\hline Montana & 1990 & 1993 & 1997 \\
\hline Nebraska & 1985 & 1990 & $* * *$ \\
\hline Nevada & 1960 & 1985 & 1960 \\
\hline New Hampshire & 1987 & 1987 & 1987 \\
\hline New Jersey & 1977 & 1986 & 1996 \\
\hline New Mexico & 1991 & 1989 & 1991 \\
\hline New York & 1976 & 1982 & $* * *$ \\
\hline North Carolina & 1960 & 1985 & 1960 \\
\hline North Dakota & 1987 & 1991 & 1996 \\
\hline Ohio & 1979 & 1985 & 1989 \\
\hline Oklahoma & 1988 & 1987 & 2000 \\
\hline Oregon & 1985 & 1986 & 1985 \\
\hline Pennsylvania & 1982 & 1986 & 1989 \\
\hline Rhode Island & 1960 & 1984 & 1960 \\
\hline South Carolina & 1960 & 1986 & 1960 \\
\hline South Dakota & 1960 & 1988 & 1960 \\
\hline Tennessee & 1985 & 1985 & 1990 \\
\hline Texas & 1988 & 1987 & 1988 \\
\hline Utah & 1981 & 1984 & 1981 \\
\hline Vermont & 1970 & 1988 & 1970 \\
\hline Virginia & 1978 & 1985 & 1986 \\
\hline Washington & 1985 & 1987 & 1985 \\
\hline West Virginia & 1987 & 1988 & 1987 \\
\hline Wisconsin & 1990 & 1987 & 1989 \\
\hline Wyoming & 1988 & 1987 & 1999 \\
\hline
\end{tabular}

Source: Amel (1993), Kroszner and Strahan (1999), and authors' updates from individual states' State Codes available from the State Legislatures. For states that deregulated before 1960 the date is listed as 1960. ${ }^{* * *}$ indicates that states did not deregulate until the end of the sample period, 2001. 
Table 2:

Measures of Banking Deregulation. Descriptive Statistics

\begin{tabular}{|c|c|c|c|c|c|}
\hline \multicolumn{6}{|c|}{ Means and Standard Deviations } \\
\hline & & Mean & Std. Dev. & \multicolumn{2}{|c|}{ Sample } \\
\hline $\mathrm{D}^{\mathrm{m} \& \mathrm{a}}$ & & 0.60 & 0.49 & \multicolumn{2}{|c|}{$1970-2001$} \\
\hline$D^{\text {novo }}$ & & 0.47 & 0.50 & \multicolumn{2}{|c|}{$1970-2001$} \\
\hline$D^{\text {inter }}$ & & 0.48 & 0.50 & \multicolumn{2}{|c|}{$1970-2001$} \\
\hline $\mathrm{D}^{\text {reci }}$ & & 0.35 & 0.44 & \multicolumn{2}{|c|}{$1970-2001$} \\
\hline TECH & & 6.92 & 0.13 & \multicolumn{2}{|c|}{$1970-2001$} \\
\hline \multicolumn{6}{|c|}{ Correlations } \\
\hline & $\mathrm{D}^{\mathrm{m} \& \mathrm{a}}$ & $D^{\text {novo }}$ & $\mathrm{D}^{\text {inter }}$ & $\mathrm{D}^{\text {reci }}$ & TECH \\
\hline $\mathrm{D}^{\mathrm{m} \& \mathrm{a}}$ & 1.00 & 0.76 & 0.64 & 0.59 & 0.35 \\
\hline$D^{\text {novo }}$ & - & 1.00 & 0.51 & 0.51 & 0.35 \\
\hline$D^{\text {inter }}$ & - & - & 1.00 & 0.83 & 0.60 \\
\hline $\mathrm{D}^{\mathrm{reci}}$ & - & - & - & 1.00 & 0.62 \\
\hline TECH & - & - & - & - & 1.00 \\
\hline
\end{tabular}

Note: $\mathrm{D}^{\mathrm{m} \& \mathrm{a}}$ is an indicator variable that equals one in years where statewide branching by mergers and acquisitions were permitted; $\mathrm{D}^{\text {novo }}$ is an indicator variable that equals one in years when statewide de novo branching was permitted; $\mathrm{D}^{\text {inter }}$ is an indicator variable which equals one in years where entry by out-of-state bank holding companies were permitted. $\mathrm{D}^{\text {reci }}$ is the fraction of (outside) states in the sample from which entry is de facto allowed, taking into account whether the reciprocity constraint for each individual outside state is binding or not. TECH (lending technology) is the log of the value of bank loans scaled by the number of bank employees in state $i$ at date $t$. The correlation of TECH with the other variables is the calculated for TECH minus the mean for each state corresponding to the way it is interacted with output growth in the regression tables. Sample is 1970-2001; District of Columbia and the states of Delaware and South Dakota are excluded. 
Table 3:

Banking Deregulation and Income Insurance

\begin{tabular}{|c|c|c|c|c|c|c|c|c|c|}
\hline & (1) & $(2)$ & (3) & (4) & (5) & $(6)$ & (7) & (8) & (9) \\
\hline GSP & $\begin{array}{l}45.0 \\
(2.7)\end{array}$ & $\begin{array}{l}46.1 \\
(2.4)\end{array}$ & $\begin{array}{l}46.8 \\
(2.1)\end{array}$ & $\begin{array}{l}46.4 \\
(2.0)\end{array}$ & $\begin{array}{l}44.8 \\
(2.7)\end{array}$ & $\begin{array}{l}44.9 \\
(2.7)\end{array}$ & $\begin{array}{l}46.6 \\
(2.1)\end{array}$ & $\begin{array}{l}44.8 \\
(2.7)\end{array}$ & $\begin{array}{r}44.7 \\
(2.4)\end{array}$ \\
\hline \multicolumn{10}{|c|}{ INTRASTATE DEREGULATION } \\
\hline $\mathrm{GSP} \cdot \mathrm{D}^{\mathrm{m} \& \mathrm{a}}$ & $\begin{array}{l}10.3 \\
(3.0)\end{array}$ & $\begin{array}{l}- \\
-\end{array}$ & $\begin{array}{l}- \\
-\end{array}$ & $\begin{array}{l}- \\
-\end{array}$ & $\begin{array}{c}4.5 \\
(5.1)\end{array}$ & $\begin{array}{c}8.5 \\
(4.1)\end{array}$ & - & $\begin{array}{c}3.5 \\
(3.7)\end{array}$ & $\begin{array}{l}- \\
-\end{array}$ \\
\hline $\mathrm{GSP} \cdot \mathrm{D}^{\text {novo }}$ & $\begin{array}{l}- \\
-\end{array}$ & $\begin{array}{c}9.5 \\
(3.1)\end{array}$ & - & $\begin{array}{l}- \\
-\end{array}$ & $\begin{array}{l}-0.3 \\
(4.0)\end{array}$ & $\begin{array}{c}2.2 \\
(4.2)\end{array}$ & - & - & $\begin{array}{r}5.2 \\
(3.5)\end{array}$ \\
\hline \multicolumn{10}{|c|}{ INTERSTATE DEREGULATION } \\
\hline GSP $\cdot D^{\text {inter }}$ & $\begin{array}{l}- \\
-\end{array}$ & - & $\begin{array}{l}11.8 \\
(2.3)\end{array}$ & $\begin{array}{l}- \\
-\end{array}$ & $\begin{array}{l}-4.9 \\
(5.2)\end{array}$ & - & $\begin{array}{l}-3.1 \\
(4.4)\end{array}$ & - & $\begin{array}{r}9.5 \\
(2.4)\end{array}$ \\
\hline $\mathrm{GSP} \cdot \mathrm{D}^{\mathrm{reci}}$ & $\begin{array}{l}- \\
-\end{array}$ & $\begin{array}{l}- \\
-\end{array}$ & $\begin{array}{l}- \\
-\end{array}$ & $\begin{array}{l}17.6 \\
(3.3)\end{array}$ & $\begin{array}{l}20.2 \\
(6.0)\end{array}$ & - & $\begin{array}{l}20.9 \\
(6.3)\end{array}$ & $\begin{array}{l}15.4 \\
(3.8)\end{array}$ & $\begin{array}{l}- \\
-\end{array}$ \\
\hline \multicolumn{10}{|c|}{ LINEAR TERMS } \\
\hline $\mathrm{D}^{\mathrm{m} \& \mathrm{a}}$ & $\begin{array}{c}-0.2 \\
(0.1)\end{array}$ & $\begin{array}{l}- \\
-\end{array}$ & $\begin{array}{l}- \\
-\end{array}$ & $\begin{array}{l}- \\
-\end{array}$ & $\begin{array}{c}-0.2 \\
(0.1)\end{array}$ & $\begin{array}{c}-0.2 \\
(0.1)\end{array}$ & - & $\begin{array}{c}-0.2 \\
(0.1)\end{array}$ & $\begin{array}{l}- \\
-\end{array}$ \\
\hline $\mathrm{D}^{\text {novo }}$ & $\begin{array}{l}- \\
-\end{array}$ & $\begin{array}{l}-0.0 \\
(0.1)\end{array}$ & $\begin{array}{l}- \\
-\end{array}$ & $\begin{array}{l}- \\
-\end{array}$ & $\begin{array}{c}0.1 \\
(0.1)\end{array}$ & $\begin{array}{c}0.1 \\
(0.1)\end{array}$ & $\begin{array}{l}- \\
-\end{array}$ & - & $\begin{array}{l}-0.0 \\
(0.1)\end{array}$ \\
\hline$D^{\text {inter }}$ & - & $\begin{array}{l}- \\
-\end{array}$ & $\begin{array}{c}-0.1 \\
(0.1)\end{array}$ & $\begin{array}{l}- \\
-\end{array}$ & $\begin{array}{c}0.1 \\
(0.1)\end{array}$ & $\begin{array}{l}- \\
-\end{array}$ & $\begin{array}{c}0.0 \\
(0.1)\end{array}$ & $\begin{array}{l}- \\
-\end{array}$ & $\begin{array}{r}-0.1 \\
(0.1)\end{array}$ \\
\hline $\mathrm{D}^{\text {reci }}$ & $\begin{array}{l}- \\
-\end{array}$ & $\begin{array}{l}- \\
-\end{array}$ & $\begin{array}{l}- \\
-\end{array}$ & $\begin{array}{c}0.1 \\
(0.2)\end{array}$ & $\begin{array}{c}0.1 \\
(0.2)\end{array}$ & $\begin{array}{l}- \\
-\end{array}$ & $\begin{array}{c}0.1 \\
(0.2)\end{array}$ & $\begin{array}{c}0.1 \\
(0.2)\end{array}$ & $\begin{array}{l}- \\
-\end{array}$ \\
\hline $\mathrm{R}^{2}$ & 0.62 & 0.62 & 0.61 & 0.62 & 0.63 & 0.62 & 0.62 & 0.63 & 0.62 \\
\hline
\end{tabular}

Note: Results are from the following GLS regressions: $\widetilde{\mathrm{GSP}} i t-\widetilde{\mathrm{PNC}}_{i t}=\alpha_{i}+\nu_{t}+\beta_{0} \widetilde{\mathrm{GSP}}_{i t}+\beta_{1} \mathrm{D}_{i t}+$ $\beta_{2} \widetilde{\mathrm{GSP}}_{i t} \cdot \mathrm{D}_{i t}+\epsilon_{i t} . \mathrm{PINC}_{i t}$ is the growth rate of (real) personal income (per capita) in state $i$ in period $t$ and $\widetilde{\mathrm{PINC}}_{i t}$ is $\mathrm{PINC}_{i t}$ minus its mean across states minus its mean across time. GSP $i t$ and $\widetilde{\mathrm{GSP}}_{i t}$ are defined similarly using gross state product. $\alpha_{i}$ (not reported) is a state fixed effect and $\nu_{t}$ (not reported) is a time fixed effect. $\mathrm{D}_{i t}$ is a variable for banking deregulation, measured in terms of four different variables: $\mathrm{D}^{\mathrm{m} \& \mathrm{a}}$ is an indicator variable that equals one in years where statewide branching by mergers and acquisitions were permitted; $\mathrm{D}^{\text {novo }}$ is an indicator variable that equals one in years when statewide de novo branching was permitted; $\mathrm{D}^{\text {inter }}$ is an indicator variable which equals one in years where entry by out-of-state bank holding companies were permitted. $\mathrm{D}^{\text {reci }}$ is the fraction of (outside) states in the sample from which entry is de facto allowed, taking into account whether the reciprocity constraint for each individual outside state is binding or not. The sample is 1970-2001; District of Columbia and the states of Delaware and South Dakota are excluded. GLS clustering-robust standard deviations are in parentheses. Coefficients and standard deviations are multiplied by 100. Number of observations is 1536 . 


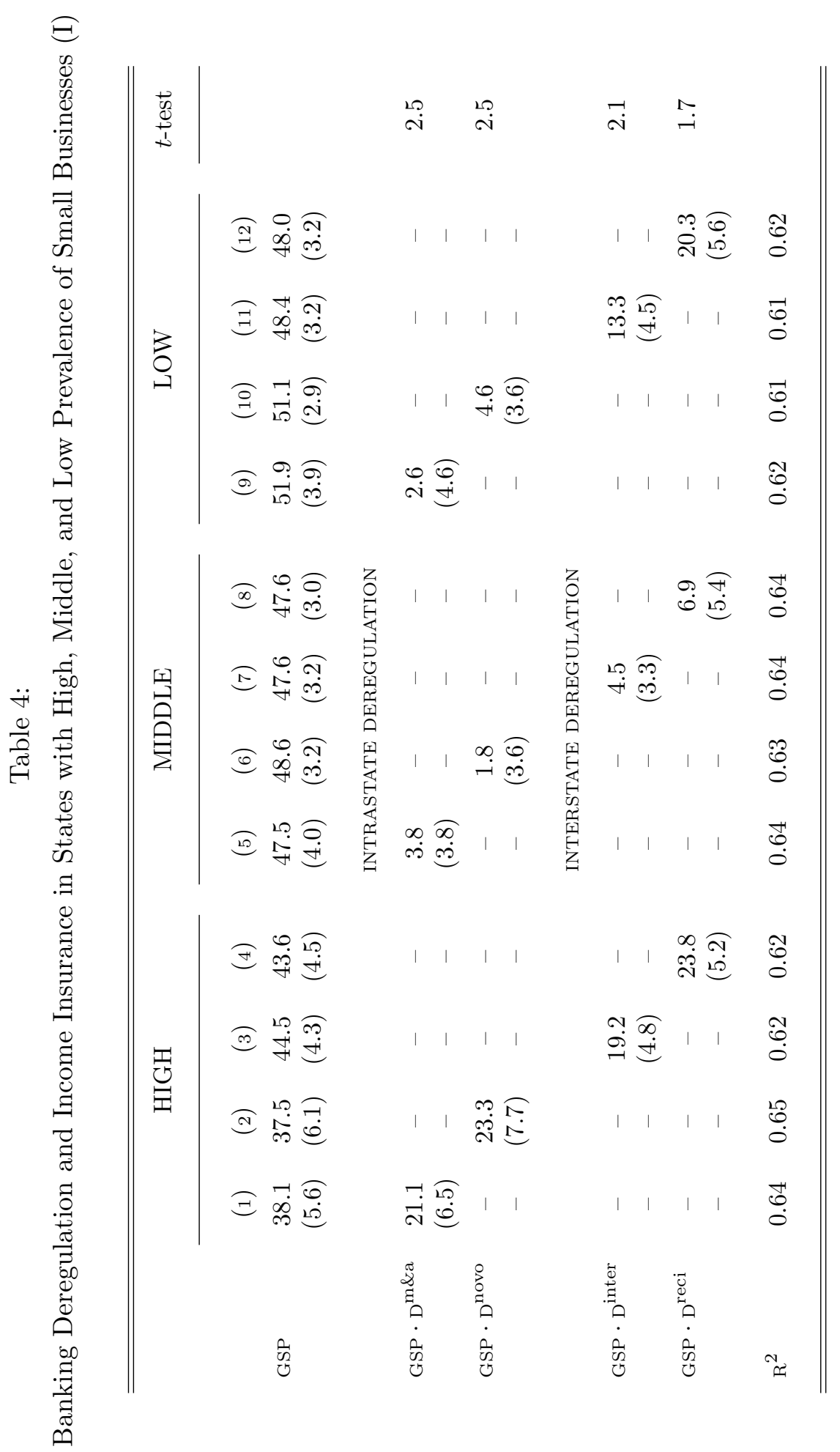

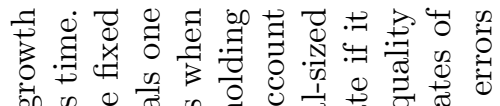

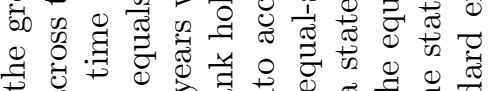

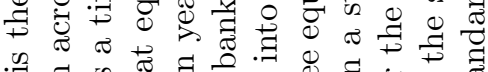

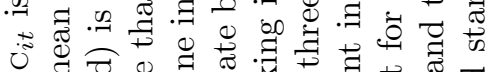

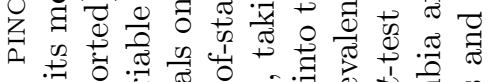

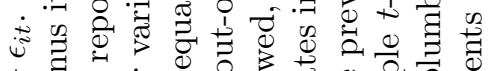

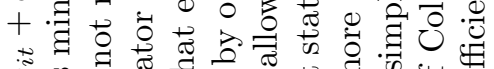

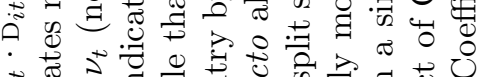

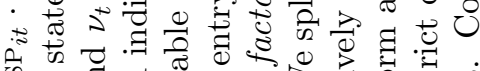

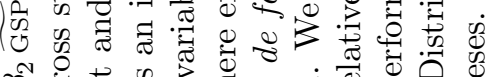
ल +

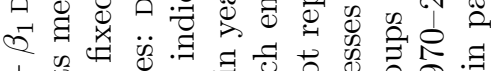

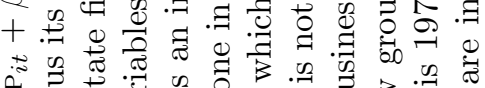

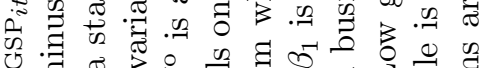
몽 + ĩ s + . w

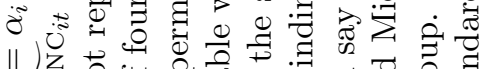

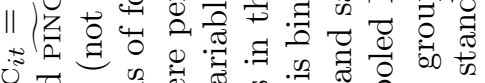

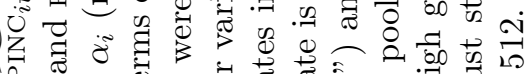

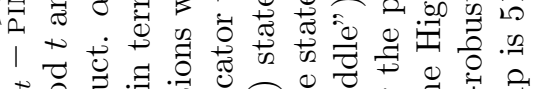

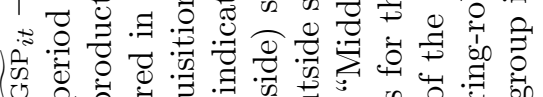
o i.

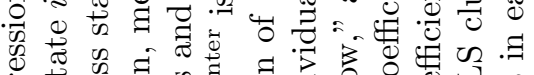

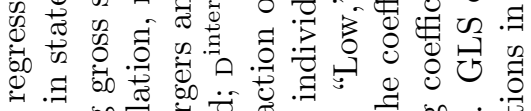
की

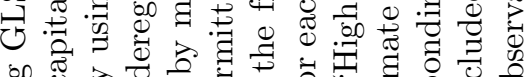
o

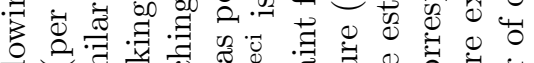

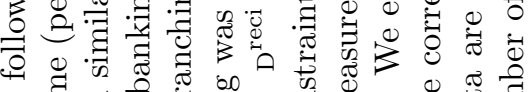

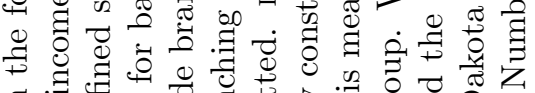

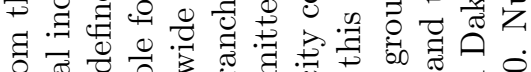

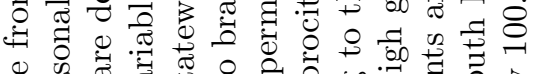

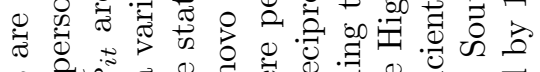

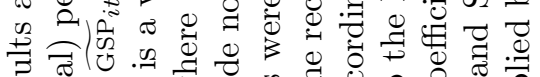

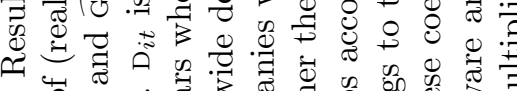

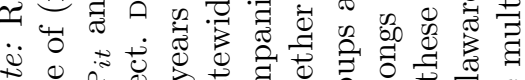

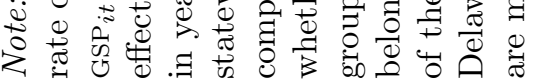


Table 5:

Banking Deregulation and Income Insurance in States with

High, Middle, and Low Prevalence of Small Businesses (II)

\begin{tabular}{|c|c|c|c|c|c|c|c|}
\hline & \multicolumn{2}{|c|}{ HIGH } & \multicolumn{2}{|c|}{ MIDDLE } & \multicolumn{2}{|c|}{ LOW } & \multirow[t]{2}{*}{$t$-test } \\
\hline & (1) & $(2)$ & (3) & $(4)$ & (5) & (6) & \\
\hline GSP & $\begin{array}{l}37.9 \\
(5.6)\end{array}$ & $\begin{array}{l}37.0 \\
(5.9)\end{array}$ & $\begin{array}{l}47.5 \\
(4.0)\end{array}$ & $\begin{array}{l}47.8 \\
(3.3)\end{array}$ & $\begin{array}{l}51.2 \\
(3.8)\end{array}$ & $\begin{array}{l}48.8 \\
(3.3)\end{array}$ & \\
\hline \multicolumn{8}{|c|}{ INTRASTATE DEREGULATION } \\
\hline $\mathrm{GSP} \cdot \mathrm{D}^{\mathrm{m} \& \mathrm{a}}$ & $\begin{array}{l}13.8 \\
(8.0)\end{array}$ & - & $\begin{array}{c}1.1 \\
(4.1)\end{array}$ & - & $\begin{array}{l}-7.4 \\
(6.1)\end{array}$ & - & 1.9 \\
\hline $\mathrm{GSP} \cdot \mathrm{D}^{\text {novo }}$ & - & $\begin{array}{l}18.9 \\
(8.5)\end{array}$ & $\begin{array}{l}- \\
-\end{array}$ & $\begin{array}{l}-0.8 \\
(3.8)\end{array}$ & - & $\begin{array}{l}-2.2 \\
(5.5)\end{array}$ & 2.3 \\
\hline \multicolumn{8}{|c|}{ INTERSTATE DEREGULATION } \\
\hline $\mathrm{GSP} \cdot \mathrm{D}^{\text {inter }}$ & - & $\begin{array}{l}10.1 \\
(4.7)\end{array}$ & - & $\begin{array}{c}5.0 \\
(3.4)\end{array}$ & - & $\begin{array}{l}15.1 \\
(5.7)\end{array}$ & 0.2 \\
\hline GSP $\cdot D^{\text {reci }}$ & $\begin{array}{l}15.2 \\
(6.0)\end{array}$ & - & $\begin{array}{c}6.2 \\
(5.9)\end{array}$ & - & $\begin{array}{l}25.8 \\
(7.0)\end{array}$ & $\begin{array}{l}- \\
-\end{array}$ & 0.1 \\
\hline $\mathrm{R}^{2}$ & 0.64 & 0.65 & 0.64 & 0.64 & 0.62 & 0.61 & \\
\hline
\end{tabular}

Note: Results are from the following GLS regressions: $\widetilde{\mathrm{GSP}_{i t}}-\widetilde{\mathrm{PINC}_{i t}}=\alpha_{i}+\nu_{t}+\beta_{0} \widetilde{\mathrm{GSP}}_{i t}+\beta_{1} \mathrm{D}_{i t}^{k}+$ $\beta_{2} \mathrm{D}_{i t}^{m}+\beta_{3} \widetilde{\mathrm{GSP}_{i t}} \cdot \mathrm{D}_{i t}^{k}+\beta_{4} \widetilde{\mathrm{GSP}_{i t}} \cdot \mathrm{D}_{i t}^{m}+\epsilon_{i t}$. PINC $i t$ is the growth rate of (real) personal income (per capita) in state $i$ in period $t$ and $\widetilde{\text { PINC }}_{i t}$ is PINC $_{i t}$ minus its mean across states minus its mean across time. GSP $i t$ and $\widetilde{\mathrm{GSP}}_{i t}$ are defined similarly using gross state product. $\alpha_{i}$ (not reported) is a state fixed effect and $\nu_{t}$ (not reported) is a time fixed effect. $\mathrm{D}_{i t}^{k}$ is a measure of intrastate deregulation: either $\mathrm{D}^{\mathrm{m} \& \mathrm{a}}$, an indicator variable that equals one in years where statewide branching by mergers and acquisitions were permitted, or $\mathrm{D}^{\text {novo }}$, an indicator variable that equals one in years when statewide de novo branching was permitted. $\mathrm{D}_{i t}^{m}$ is a measure of interstate deregulation: either $\mathrm{D}^{\text {inter }}$, an indicator variable which equals one in years where entry by out-of-state bank holding companies were permitted, or $\mathrm{D}^{\text {reci }}$, the fraction of (outside) states in the sample from which entry is de facto allowed, taking into account whether the reciprocity constraint for each individual outside state is binding or not. $\beta_{1}$ and $\beta_{2}$ are not reported. We split states into three equal-sized groups according to this measure ("High," "Low," 'and "Middle") and say that small businesses are relatively more prevalent in a state if it belongs to the High group. We estimate the coefficients for the pooled Middle and Low groups and perform a simple $t$-test for the equality of these coefficients and the corresponding coefficients of the High group. The sample is 1970-2001; District of Columbia and the states of Delaware and South Dakota are excluded. GLS clustering-robust standard deviations are in parentheses. Coefficients and are multiplied by 100. Number of observations in each group is 512 . 
Table 6:

Banking Deregulation and Income Insurance:

Robustness to Other Market Developments

\begin{tabular}{|c|c|c|c|c|c|c|}
\hline & $(1)$ & $(2)$ & $(3)$ & $(4)$ & $(5)$ & $(6)$ \\
\hline \multirow[t]{2}{*}{ GSP } & $\begin{array}{l}50.9 \\
(1.9)\end{array}$ & $\begin{array}{l}43.8 \\
(2.9)\end{array}$ & $\begin{array}{l}44.2 \\
(2.7)\end{array}$ & $\begin{array}{l}53.0 \\
(2.0)\end{array}$ & $\begin{array}{l}44.7 \\
(4.7)\end{array}$ & $\begin{array}{r}48.8 \\
(3.9)\end{array}$ \\
\hline & \multicolumn{6}{|c|}{ INTRASTATE DEREGULATION } \\
\hline \multirow{2}{*}{$\mathrm{GSP} \cdot \mathrm{D}^{\mathrm{m} \& \mathrm{a}}$} & - & 3.4 & - & - & 3.6 & - \\
\hline & - & $(3.7)$ & - & - & $(4.2)$ & - \\
\hline \multirow[t]{3}{*}{ GSP $\cdot D^{\text {novo }}$} & - & - & 5.5 & - & - & 4.2 \\
\hline & - & - & $(3.6)$ & - & - & $(4.0)$ \\
\hline & \multicolumn{6}{|c|}{ INTERSTATE DEREGULATION } \\
\hline \multirow[t]{2}{*}{ GSP $\cdot D^{\text {inter }}$} & - & - & 10.4 & - & - & 2.3 \\
\hline & - & - & $(3.1)$ & - & - & $(4.8)$ \\
\hline \multirow[t]{3}{*}{$\mathrm{GSP} \cdot \mathrm{D}^{\mathrm{reci}}$} & - & 18.4 & - & - & 15.0 & - \\
\hline & - & $(4.9)$ & - & - & $(8.3)$ & - \\
\hline & \multicolumn{6}{|c|}{ ALTERNATIVE MEASURES } \\
\hline \multirow[t]{2}{*}{ GSP $\cdot$ TECH } & 29.3 & -18.4 & -7.9 & - & - & - \\
\hline & $(12.1)$ & $(18.6)$ & $(18.7)$ & - & - & - \\
\hline \multirow[t]{2}{*}{ GSP $\cdot$ MBS } & - & - & - & 0.5 & 0.0 & 0.3 \\
\hline & - & - & - & $(0.1)$ & $(0.3)$ & $(0.2)$ \\
\hline $\mathrm{R}^{2}$ & 0.59 & 0.63 & 0.63 & 0.61 & 0.63 & 0.62 \\
\hline
\end{tabular}

Note: Results are from the following GLS regressions: $\widetilde{\operatorname{GSP}}_{i t}-\widetilde{\operatorname{PINC}}_{i t}=\alpha_{i}+\nu_{t}+\beta_{0} \widetilde{\mathrm{GSP}}_{i t}+\beta_{1} \mathrm{D}_{i t}^{k}+$ $\beta_{2} \mathrm{D}_{i t}^{m}+\beta_{3} \widetilde{\mathrm{GSP}}_{i t} \cdot \mathrm{D}_{i t}^{k}+\beta_{4} \widetilde{\mathrm{GSP}_{i t}} \cdot \mathrm{D}_{i t}^{m}+\beta_{5} \mathrm{x}_{i t}+\beta_{6} \widetilde{\mathrm{GSP}}_{i t} \cdot \mathrm{x}_{i t}+\epsilon_{i t} . \mathrm{x}_{i t}$ is $\mathrm{TECH}_{i t}$ in the first three columns and MBS $i t$ in columns four to six. TECH (lending technology) is the log of the value of bank loans scaled by the number of bank employees in state $i$ at date $t$. MBS is the ratio of the cumulative outstanding volume of mortgage backed securities issued by Government Sponsored Enterprizes scaled by U.S. GDP (divided by $10^{6}$ for scaling). PINC $_{i t}$ is the growth rate of (real) personal income (per capita) in state $i$ in period $t$ and $\widetilde{\mathrm{PINC}}_{i t}$ is PINC $_{i t}$ minus its mean across states minus its mean across time. GSP $i t$ and $\widetilde{\mathrm{GSP}}_{i t}$ are defined similarly using gross state product. $\alpha_{i}$ (not reported) is a state fixed effect and $\nu_{t}$ (not reported) is a time fixed effect. $\mathrm{D}_{i t}^{k}$ is a measure of intrastate deregulation: either $\mathrm{D}^{\mathrm{m} \& \mathrm{a}}$, an indicator variable that equals one in years where statewide branching by mergers and acquisitions were permitted, or $\mathrm{D}^{\text {novo }}$, an indicator variable that equals one in years when statewide de novo branching was permitted. $\mathrm{D}_{i t}^{m}$ is a measure of interstate deregulation: either $\mathrm{D}^{\mathrm{inter}}$, an indicator variable which equals one in years where entry by out-ofstate bank holding companies were permitted, or $\mathrm{D}^{\text {reci }}$, the fraction of (outside) states in the sample from which entry is de facto allowed, taking into account whether the reciprocity constraint for each individual outside state is binding or not. $\beta_{1}, \beta_{2}$, and $\beta_{5}$ are not reported. The sample is 1970-2001; District of Columbia and the states of Delaware and South Dakota are excluded. GLS clusteringrobust standard deviations in parentheses. Coefficients and standard deviations are multiplied by 100. Number of observations is 1536 . 
Table 7:

Banking Deregulation and Income Insurance: Robustness to Trend

\begin{tabular}{|c|c|c|c|c|c|c|}
\hline & (1) & $(2)$ & (3) & (4) & (5) & (6) \\
\hline \multirow[t]{2}{*}{ GSP } & $\begin{array}{l}48.9 \\
(3.1)\end{array}$ & $\begin{array}{l}47.9 \\
(2.6)\end{array}$ & $\begin{array}{l}52.6 \\
(2.6)\end{array}$ & $\begin{array}{l}44.9 \\
(3.1)\end{array}$ & $\begin{array}{l}44.2 \\
(4.0)\end{array}$ & $\begin{array}{c}49.8 \\
(3.3)\end{array}$ \\
\hline & \multicolumn{6}{|c|}{ INTRASTATE DEREGULATION } \\
\hline $\mathrm{GSP} \cdot \mathrm{D}^{\mathrm{m} \& \mathrm{a}}$ & $\begin{array}{c}3.3 \\
(4.7)\end{array}$ & - & $\begin{array}{l}- \\
-\end{array}$ & $\begin{array}{l}- \\
-\end{array}$ & $\begin{array}{c}1.1 \\
(4.1)\end{array}$ & $\begin{array}{l}- \\
-\end{array}$ \\
\hline \multirow[t]{2}{*}{$\mathrm{GSP} \cdot \mathrm{D}^{\text {novo }}$} & $\begin{array}{l}- \\
-\end{array}$ & $\begin{array}{c}5.6 \\
(4.6)\end{array}$ & $\begin{array}{l}- \\
-\end{array}$ & $\begin{array}{l}- \\
-\end{array}$ & $\begin{array}{l}- \\
-\end{array}$ & $\begin{array}{r}6.3 \\
(4.4)\end{array}$ \\
\hline & \multicolumn{6}{|c|}{ INTERSTATE DEREGULATION } \\
\hline $\mathrm{GSP} \cdot \mathrm{D}^{\text {inter }}$ & - & $\begin{array}{l}- \\
-\end{array}$ & $\begin{array}{l}-3.4 \\
(4.3)\end{array}$ & $\begin{array}{l}- \\
-\end{array}$ & $\begin{array}{l}- \\
-\end{array}$ & $\begin{array}{c}-4.9 \\
(3.9)\end{array}$ \\
\hline \multirow[t]{2}{*}{$\mathrm{GSP} \cdot \mathrm{D}^{\mathrm{reci}}$} & - & - & $\begin{array}{l}- \\
-\end{array}$ & $\begin{array}{l}16.9 \\
(8.2)\end{array}$ & $\begin{array}{l}16.7 \\
(7.8)\end{array}$ & $\begin{array}{l}- \\
-\end{array}$ \\
\hline & \multicolumn{6}{|c|}{ QUADRATIC TREND } \\
\hline GSP $\cdot$ TREND & $\begin{array}{c}0.9 \\
(0.2)\end{array}$ & $\begin{array}{c}0.9 \\
(0.2)\end{array}$ & $\begin{array}{c}1.2 \\
(0.3)\end{array}$ & $\begin{array}{c}0.3 \\
(0.4)\end{array}$ & $\begin{array}{c}0.3 \\
(0.4)\end{array}$ & $\begin{array}{c}1.1 \\
(0.3)\end{array}$ \\
\hline GSP $\cdot$ TREND ${ }^{2}$ & $\begin{array}{l}-0.1 \\
(0.0)\end{array}$ & $\begin{array}{l}-0.1 \\
(0.0)\end{array}$ & $\begin{array}{c}-0.1 \\
(0.0)\end{array}$ & $\begin{array}{l}-0.1 \\
(0.0)\end{array}$ & $\begin{array}{l}-0.1 \\
(0.0)\end{array}$ & $\begin{array}{c}-0.1 \\
(0.0)\end{array}$ \\
\hline $\mathrm{R}^{2}$ & 0.64 & 0.65 & 0.63 & 0.65 & 0.65 & 0.64 \\
\hline
\end{tabular}

Note: Results are from the following GLS regressions: $\widetilde{\mathrm{GSP}_{i t}}-\widetilde{\mathrm{PINC}}_{i t}=\alpha_{i}+\beta_{0} \widetilde{\mathrm{GSP}}_{i t}+\beta_{1} \mathrm{D}_{i t}^{k}+\beta_{2} \mathrm{D}_{i t}^{m}+$ $\beta_{3} \widetilde{\mathrm{GSP}}_{i t} \cdot \mathrm{D}_{i t}^{k}+\beta_{4} \widetilde{\mathrm{GSP}}_{i t} \cdot \mathrm{D}_{i t}^{m}+\beta_{5} t+\beta_{6} t^{2}+\epsilon_{i t}$. $\mathrm{PINC}_{i t}$ is the growth rate of (real) personal income (per capita) in state $i$ in period $t$ and $\widetilde{P I N C}_{i t}$ is PINC $_{i t}$ minus its mean across states minus its mean across time. GSP $i t$ and $\widetilde{\mathrm{GSP}}_{i t}$ are defined similarly using gross state product. $\alpha_{i}$ (not reported) is a state fixed effect. $\mathrm{D}_{i t}^{k}$ is a measure of intrastate deregulation: either $\mathrm{D}^{\mathrm{m} \& \mathrm{a}}$, an indicator variable that equals one in years where statewide branching by mergers and acquisitions were permitted, or $\mathrm{D}^{\text {novo }}$, an indicator variable that equals one in years when statewide de novo branching was permitted. $\mathrm{D}_{i t}^{m}$ is a measure of interstate deregulation: either $\mathrm{D}^{\text {inter }}$, an indicator variable which equals one in years where entry by out-of-state bank holding companies were permitted, or $\mathrm{D}^{\text {reci }}$, the fraction of (outside) states in the sample from which entry is de facto allowed, taking into account whether the reciprocity constraint for each individual outside state is binding or not. $\beta_{1}$ and $\beta_{2}$ are not reported. The sample is 1970-2001; District of Columbia and the states of Delaware and South Dakota are excluded. GLS clustering-robust standard deviations are in parentheses. Coefficients and standard deviations are multiplied by 100. Number of observations is 1536 . 
Table 8:

Banking Deregulation and Income Insurance in States with

High, Middle, and Low Prevalence of Small Businesses: Robustness to Trend

\begin{tabular}{|c|c|c|c|c|c|c|c|}
\hline \multirow[b]{2}{*}{ GSP } & \multicolumn{2}{|c|}{ HIGH } & \multicolumn{2}{|c|}{ MIDDLE } & \multicolumn{2}{|c|}{ LOW } & $t$-test \\
\hline & $\begin{array}{c}(1) \\
34.0 \\
(6.7)\end{array}$ & $\begin{array}{c}(2) \\
36.9 \\
(6.9)\end{array}$ & $\begin{array}{c}(3) \\
52.2 \\
(4.7)\end{array}$ & $\begin{array}{c}(4) \\
53.5 \\
(3.6)\end{array}$ & $\begin{array}{c}(5) \\
50.0 \\
(8.7)\end{array}$ & $\begin{array}{c}(6) \\
62.4 \\
(4.5)\end{array}$ & \\
\hline \multicolumn{8}{|c|}{ INTRASTATE DEREGULATION } \\
\hline $\mathrm{GSP} \cdot \mathrm{D}^{\mathrm{m \& a}}$ & $\begin{array}{l}16.0 \\
(8.6)\end{array}$ & - & $\begin{array}{l}-3.8 \\
(4.0)\end{array}$ & $\begin{array}{l}- \\
-\end{array}$ & $\begin{array}{c}-11.6 \\
(4.7)\end{array}$ & - & 2.6 \\
\hline GSP $\cdot D^{\text {novo }}$ & $\begin{array}{l}- \\
-\end{array}$ & $\begin{array}{l}21.4 \\
(8.7)\end{array}$ & $\begin{array}{l}- \\
-\end{array}$ & $\begin{array}{l}-0.8 \\
(3.7)\end{array}$ & $\begin{array}{l}- \\
-\end{array}$ & $\begin{array}{l}-3.2 \\
(4.5)\end{array}$ & 2.6 \\
\hline \multicolumn{8}{|c|}{ INTERSTATE DEREGULATION } \\
\hline $\mathrm{GSP} \cdot \mathrm{D}^{\text {inter }}$ & $\begin{array}{l}- \\
-\end{array}$ & $\begin{array}{c}3.8 \\
(6.8)\end{array}$ & $\begin{array}{l}- \\
-\end{array}$ & $\begin{array}{l}-9.2 \\
(5.0)\end{array}$ & $\begin{array}{l}- \\
-\end{array}$ & $\begin{array}{c}-13.4 \\
(8.9)\end{array}$ & 1.9 \\
\hline GSP $\cdot D^{\text {reci }}$ & $\begin{array}{l}16.3 \\
(9.2)\end{array}$ & $\begin{array}{l}- \\
-\end{array}$ & $\begin{array}{c}-3.0 \\
(10.4)\end{array}$ & $\begin{array}{l}- \\
-\end{array}$ & $\begin{array}{c}33.8 \\
(18.6)\end{array}$ & $\begin{array}{l}- \\
-\end{array}$ & 0.8 \\
\hline \multicolumn{8}{|c|}{ QUADRATIC TREND } \\
\hline GSP $\cdot$ TREND & $\begin{array}{c}0.0 \\
(0.6)\end{array}$ & $\begin{array}{c}0.5 \\
(0.6)\end{array}$ & $\begin{array}{c}1.0 \\
(0.6)\end{array}$ & $\begin{array}{c}1.2 \\
(0.4)\end{array}$ & $\begin{array}{c}0.2 \\
(0.9)\end{array}$ & $\begin{array}{c}1.9 \\
(0.6)\end{array}$ & \\
\hline GSP $\cdot$ TREND ${ }^{2}$ & $\begin{array}{l}-0.2 \\
(0.0)\end{array}$ & $\begin{array}{l}-0.2 \\
(0.0)\end{array}$ & $\begin{array}{l}-0.1 \\
(0.0)\end{array}$ & $\begin{array}{l}-0.0 \\
(0.0)\end{array}$ & $\begin{array}{l}-0.1 \\
(0.1)\end{array}$ & $\begin{array}{l}-0.1 \\
(0.0)\end{array}$ & \\
\hline $\mathrm{R}^{2}$ & 0.69 & 0.70 & 0.65 & 0.65 & 0.63 & 0.63 & \\
\hline
\end{tabular}

Note: Results are from the following GLS regressions: $\widetilde{\mathrm{GSP}_{i t}}-\widetilde{\mathrm{PINC}}_{i t}=\alpha_{i}+\beta_{0} \widetilde{\mathrm{GSP}}_{i t}+\beta_{1} \mathrm{D}_{i t}^{k}+\beta_{2} \mathrm{D}_{i t}^{m}+$ $\beta_{3} \widetilde{\mathrm{GSP}}_{i t} \cdot \mathrm{D}_{i t}^{k}+\beta_{4} \widetilde{\mathrm{GSP}_{i t}} \cdot \mathrm{D}_{i t}^{m}+\beta_{5} t+\beta_{6} t^{2}+\epsilon_{i t}$. $\mathrm{PINC}_{i t}$ is the growth rate of (real) personal income (per capita) in state $i$ in period $t$ and $\widetilde{P I N C}_{i t}$ is PINC $_{i t}$ minus its mean across states minus its mean across time. GSP $i t$ and $\widetilde{G} S P_{i t}$ are defined similarly using gross state product. $\alpha_{i}$ (not reported) is a state fixed effect. $\mathrm{D}_{i t}^{k}$ is a measure of intrastate deregulation: either $\mathrm{D}^{\mathrm{m} \& \mathrm{a}}$, an indicator variable that equals one in years where statewide branching by mergers and acquisitions were permitted, or $\mathrm{D}^{\text {novo }}$, an indicator variable that equals one in years when statewide de novo branching was permitted. $\mathrm{D}_{i t}^{m}$ is a measure of interstate deregulation: either $\mathrm{D}^{\text {inter }}$, an indicator variable which equals one in years where entry by out-of-state bank holding companies were permitted, or $\mathrm{D}^{\text {reci }}$, the fraction of (outside) states in the sample from which entry is de facto allowed, taking into account whether the reciprocity constraint for each individual outside state is binding or not. $\beta_{1}$ and $\beta_{2}$ are not reported. We split states into three equal-sized groups according to this measure ("High," "Low," and "Middle") and say that small businesses are relatively more prevalent in a state if it belongs to the High group. We estimate the coefficients for the pooled Middle and Low groups and perform a simple $t$-test for the equality of the these coefficients and the corresponding coefficients of the High group. The sample is 1970-2001; District of Columbia and the states of Delaware and South Dakota are excluded. GlS clustering-robust standard deviations are in parentheses. Coefficients and standard errors are multiplied by 100. Numbers of observations in each group is 512 . 
Table 9:

Banking Deregulation and Sensitivity of Personal Income Components to Output

\begin{tabular}{|c|c|c|c|c|c|c|c|c|}
\hline & \multicolumn{4}{|c|}{ Proprietors' Income } & \multicolumn{2}{|c|}{ Wages } & \multicolumn{2}{|c|}{ Int., Div. \& Rent } \\
\hline & $(1)$ & $(2)$ & (3) & (4) & $(5)$ & (6) & (7) & (8) \\
\hline GSP & $\begin{array}{l}288.4 \\
(40.5)\end{array}$ & $\begin{array}{l}263.7 \\
(37.1)\end{array}$ & $\begin{array}{l}342.8 \\
(48.2)\end{array}$ & $\begin{array}{l}294.9 \\
(42.8)\end{array}$ & $\begin{array}{l}51.6 \\
(3.8)\end{array}$ & $\begin{array}{l}54.7 \\
(3.8)\end{array}$ & $\begin{array}{l}21.7 \\
(3.0)\end{array}$ & $\begin{array}{c}20.6 \\
(2.8)\end{array}$ \\
\hline \multicolumn{9}{|c|}{ INTRASTATE DEREGULATION } \\
\hline $\mathrm{GSP} \cdot \mathrm{D}^{\mathrm{m} \& \mathrm{a}}$ & $\begin{array}{c}-204.0 \\
(64.0)\end{array}$ & $\begin{array}{l}- \\
-\end{array}$ & $\begin{array}{c}-195.8 \\
(57.2)\end{array}$ & - & $\begin{array}{l}19.1 \\
(4.3)\end{array}$ & $\begin{array}{l}- \\
-\end{array}$ & $\begin{array}{l}-7.8 \\
(8.0)\end{array}$ & $\begin{array}{l}- \\
-\end{array}$ \\
\hline $\mathrm{GSP} \cdot \mathrm{D}^{\text {novo }}$ & $\begin{array}{l}- \\
-\end{array}$ & $\begin{array}{c}-175.4 \\
(62.2)\end{array}$ & - & $\begin{array}{c}-139.5 \\
(60.0)\end{array}$ & $\begin{array}{l}- \\
-\end{array}$ & $\begin{array}{c}8.6 \\
(4.1)\end{array}$ & $\begin{array}{l}- \\
-\end{array}$ & $\begin{array}{l}-7.7 \\
(7.1)\end{array}$ \\
\hline \multicolumn{9}{|c|}{ INTERSTATE DEREGULATION } \\
\hline $\mathrm{GSP} \cdot \mathrm{D}^{\text {inter }}$ & $\begin{array}{l}- \\
-\end{array}$ & $\begin{array}{c}-63.2 \\
(31.9)\end{array}$ & $\begin{array}{l}- \\
-\end{array}$ & $\begin{array}{c}-133.4 \\
(41.0)\end{array}$ & $\begin{array}{l}- \\
-\end{array}$ & $\begin{array}{c}-11.6 \\
(4.1)\end{array}$ & $\begin{array}{l}- \\
-\end{array}$ & $\begin{array}{r}3.6 \\
(5.9)\end{array}$ \\
\hline GSP $\cdot D^{\text {reci }}$ & $\begin{array}{l}-65.8 \\
(31.7)\end{array}$ & $\begin{array}{l}- \\
-\end{array}$ & $\begin{array}{c}-172.6 \\
(30.0)\end{array}$ & $\begin{array}{l}- \\
-\end{array}$ & $\begin{array}{c}-26.9 \\
(5.1)\end{array}$ & $\begin{array}{l}- \\
-\end{array}$ & $\begin{array}{c}3.0 \\
(7.0)\end{array}$ & $\begin{array}{l}- \\
-\end{array}$ \\
\hline \multicolumn{9}{|c|}{ QUADRATIC TREND } \\
\hline GSP $\cdot$ TREND & $\begin{array}{l}- \\
-\end{array}$ & $\begin{array}{l}- \\
-\end{array}$ & $\begin{array}{c}6.2 \\
(2.1)\end{array}$ & $\begin{array}{c}3.7 \\
(2.4)\end{array}$ & $\begin{array}{l}- \\
-\end{array}$ & $\begin{array}{l}- \\
-\end{array}$ & $\begin{array}{l}- \\
-\end{array}$ & - \\
\hline GSP $\cdot$ TREND $^{2}$ & $\begin{array}{l}- \\
-\end{array}$ & - & $\begin{array}{l}-0.3 \\
(0.2)\end{array}$ & $\begin{array}{l}-0.4 \\
(0.2)\end{array}$ & - & $\begin{array}{l}- \\
-\end{array}$ & $\begin{array}{l}- \\
-\end{array}$ & $\begin{array}{l}- \\
-\end{array}$ \\
\hline $\mathrm{R}^{2}$ & 0.05 & 0.04 & 0.05 & 0.05 & 0.49 & 0.47 & 0.07 & 0.08 \\
\hline
\end{tabular}

Note: Results are from the following GLS regressions: $\widetilde{\mathrm{INC}}_{i t}=\alpha_{i}+\beta_{0} \widetilde{\mathrm{GSP}}_{i t}+\beta_{1} \mathrm{D}_{i t}^{k}+\beta_{2} \mathrm{D}_{i t}^{m}+$ $\beta_{3} \widetilde{\mathrm{GSP}}_{i t} \cdot \mathrm{D}_{i t}^{k}+\beta_{4} \widetilde{\mathrm{GSP}_{i t}} \cdot \mathrm{D}_{i t}^{m}+\beta_{5} t+\beta_{6} t^{2}+\epsilon_{i t}$. INC $i t$ is the growth rate of (real) personal income components (per capita) in state $i$ in period $t$ and $\widetilde{\mathrm{INC}}_{i t}$ is $\mathrm{INC}_{i t}$ minus its mean across states minus its mean across time. GSP $i t$ and $\widetilde{\mathrm{GSP}}_{i t}$ are defined similarly using gross state product. In columns (1)-(4), $\mathrm{INC}_{i t}$ is proprietors' income, in columns (5) and (6) - wages, and in columns (7) and (8) -income from dividends, interest, and rent. $\alpha_{i}$ (not reported) is a state fixed effect. $\mathrm{D}_{i t}^{k}$ is a measure of intrastate deregulation: either $\mathrm{D}^{\mathrm{m} \& \mathrm{a}}$, an indicator variable that equals one in years where statewide branching by mergers and acquisitions were permitted, or $\mathrm{D}^{\text {novo }}$, an indicator variable that equals one in years when statewide de novo branching was permitted. $\mathrm{D}_{i t}^{m}$ is a measure of interstate deregulation: either $\mathrm{D}^{\mathrm{inter}}$, an indicator variable which equals one in years where entry by out-ofstate bank holding companies were permitted, or $\mathrm{D}^{\text {reci }}$, the fraction of (outside) states in the sample from which entry is de facto allowed, taking into account whether the reciprocity constraint for each individual outside state is binding or not. $\beta_{1}$ and $\beta_{2}$ are not reported. The sample is 1970-2001; District of Columbia and the states of Delaware and South Dakota are excluded. GLS clusteringrobust standard deviations are in parentheses. Coefficients and standard deviations are multiplied by 100 . Number of observations is 1536 . 
Table 10:

Banking Deregulation and Income Insurance. Robustness test: Omitting Alaska and Wyoming

\begin{tabular}{|c|c|c|c|c|}
\hline & $(1)$ & $(2)$ & $(3)$ & (4) \\
\hline & \multicolumn{4}{|c|}{ INTRASTATE DEREGULATION } \\
\hline $\mathrm{GSP} \cdot \mathrm{D}^{\mathrm{m} \& \mathrm{a}}$ & $\begin{array}{l}-1.0 \\
(3.6)\end{array}$ & $\begin{array}{l}- \\
-\end{array}$ & $\begin{array}{l}-7.8 \\
(3.1)\end{array}$ & $\begin{array}{l}- \\
-\end{array}$ \\
\hline \multirow[t]{2}{*}{$\mathrm{GSP} \cdot \mathrm{D}^{\text {novo }}$} & $\begin{array}{l}- \\
-\end{array}$ & $\begin{array}{l}-1.3 \\
(3.4)\end{array}$ & $\begin{array}{l}- \\
-\end{array}$ & $\begin{array}{c}-3.4 \\
(3.1)\end{array}$ \\
\hline & \multicolumn{4}{|c|}{ INTERSTATE DEREGULATION } \\
\hline $\mathrm{GSP} \cdot \mathrm{D}^{\text {inter }}$ & $\begin{array}{l}- \\
-\end{array}$ & $\begin{array}{l}13.4 \\
(3.0)\end{array}$ & $\begin{array}{l}- \\
-\end{array}$ & $\begin{array}{l}-8.1 \\
(3.9)\end{array}$ \\
\hline \multirow[t]{3}{*}{$\mathrm{GSP} \cdot \mathrm{D}^{\mathrm{reci}}$} & $\begin{array}{l}16.8 \\
(4.5)\end{array}$ & $\begin{array}{l}- \\
-\end{array}$ & $\begin{array}{c}0.9 \\
(7.4)\end{array}$ & $\begin{array}{l}- \\
-\end{array}$ \\
\hline & \multicolumn{4}{|c|}{ QUADRATIC TREND } \\
\hline & no & no & yes & yes \\
\hline $\mathrm{R}^{2}$ & 0.44 & 0.43 & 0.48 & 0.47 \\
\hline
\end{tabular}

Note: Results are from the following GLS regressions: $\widetilde{\mathrm{GSP}_{i t}}-{\widetilde{\mathrm{PINC}_{i t}}}_{i t}=\alpha_{i}+\beta_{0} \widetilde{\mathrm{GSP}}_{i t}+\beta_{1} \mathrm{D}_{i t}^{k}+\beta_{2} \mathrm{D}_{i t}^{m}+$ $\beta_{3} \widetilde{\mathrm{GSP}}_{i t} \cdot \mathrm{D}_{i t}^{k}+\beta_{4} \widetilde{\mathrm{GSP}} i t \cdot \mathrm{D}_{i t}^{m}+\beta_{5} t+\beta_{6} t^{2}+\epsilon_{i t} . \mathrm{PINC}_{i t}$ is the growth rate of (real) personal income (per capita) in state $i$ in period $t$ and $\widetilde{P I N C}_{i t}$ is PINC $_{i t}$ minus its mean across states minus its mean across time. GSP $i t$ and $\widetilde{\operatorname{GSP}}_{i t}$ are defined similarly using gross state product. $\alpha_{i}$ (not reported) is a state fixed effect. $\mathrm{D}_{i t}^{k}$ is a measure of intrastate deregulation: either $\mathrm{D}^{\mathrm{m} \& \mathrm{a}}$, an indicator variable that equals one in years where statewide branching by mergers and acquisitions were permitted, or $\mathrm{D}^{\text {novo }}$, an indicator variable that equals one in years when statewide de novo branching was permitted. $\mathrm{D}_{i t}^{m}$ is a measure of interstate deregulation: either $\mathrm{D}^{\text {inter }}$, an indicator variable which equals one in years where entry by out-of-state bank holding companies were permitted, or $\mathrm{D}^{\text {reci }}$, the fraction of (outside) states in the sample from which entry is de facto allowed, taking into account whether the reciprocity constraint for each individual outside state is binding or not. $\beta_{1}, \beta_{2}, \beta_{5}$, and $\beta_{6}$ are not reported. The sample is 1970-2001; D.C and Delaware, South Dakota, Alaska, and Wyoming are excluded. GLS clustering-robust standard deviations are in parentheses. Coefficients and standard errors are multiplied by 100. Number of observations is 1472 . 


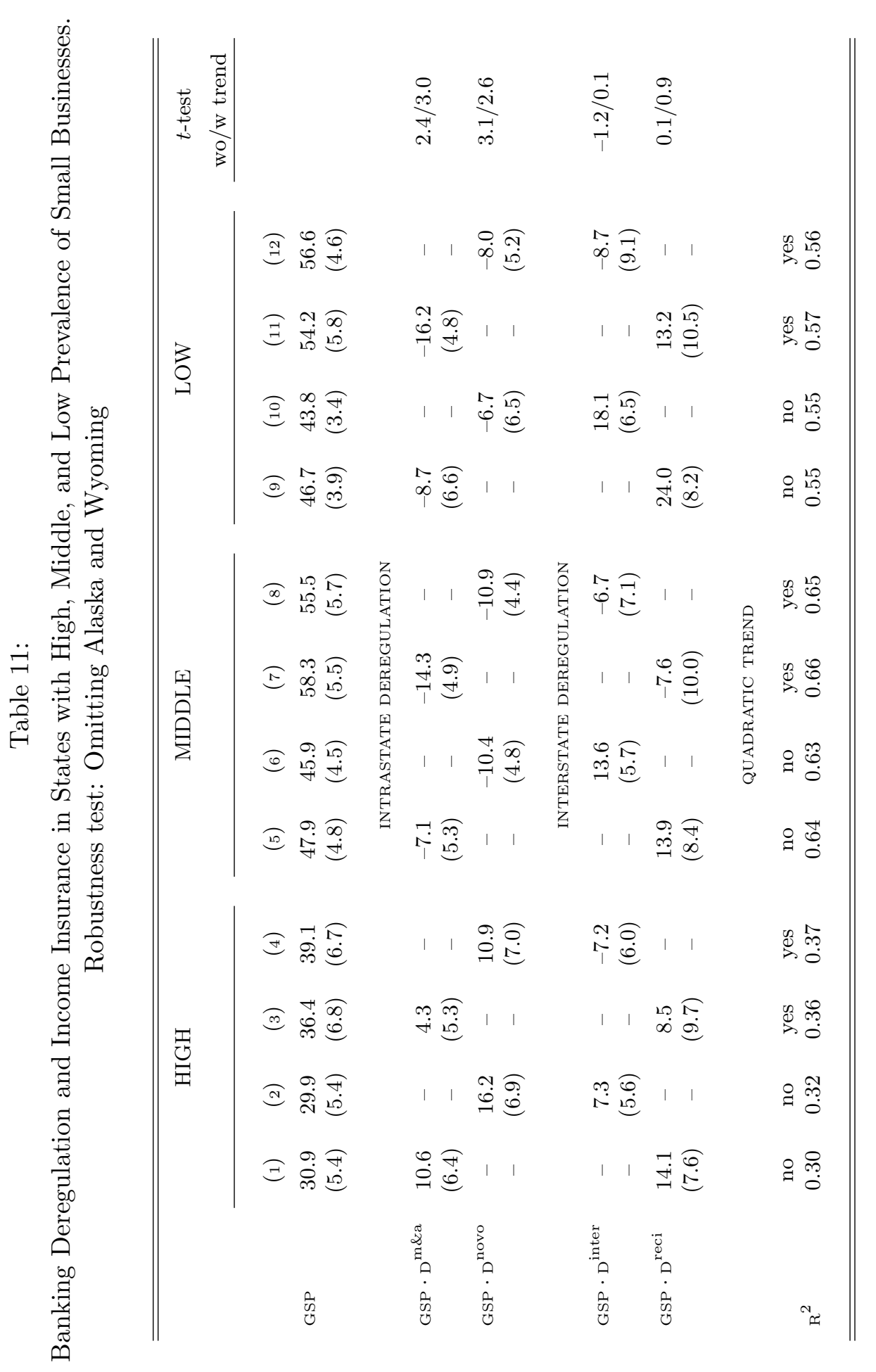

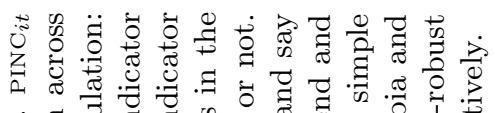

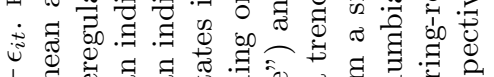

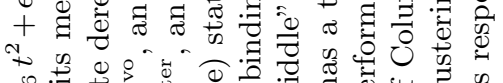

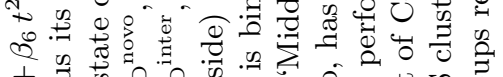

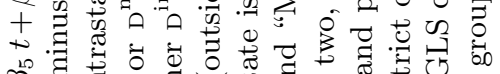

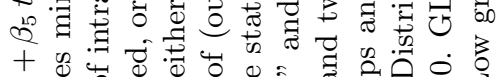
+ to

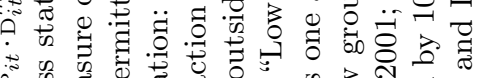

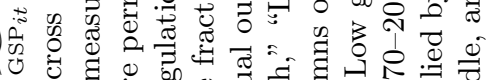

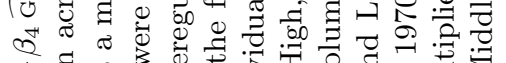

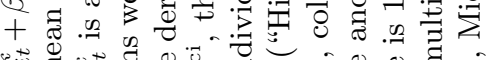

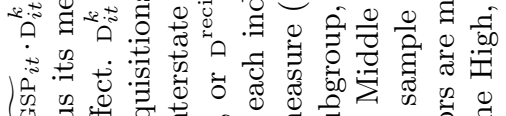

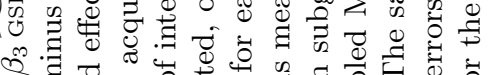

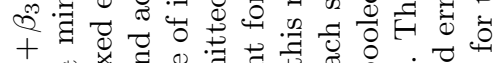

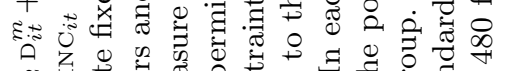

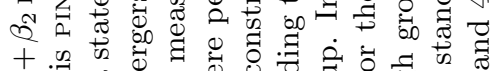

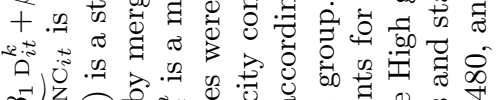
c|l

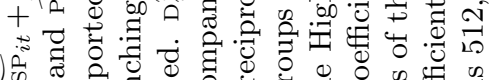

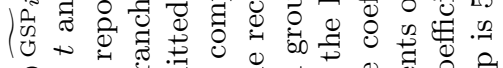
o. $+\%$

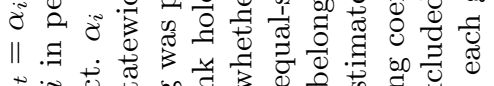

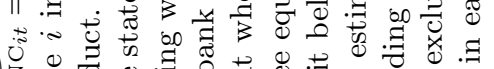

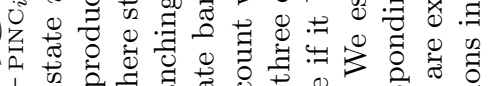

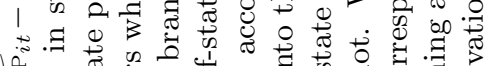

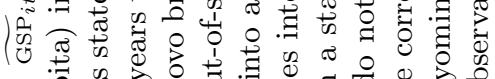
i.

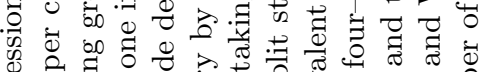

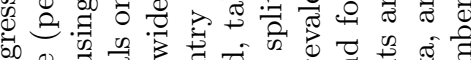

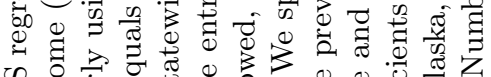

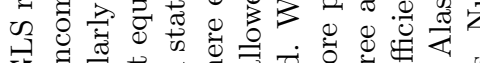

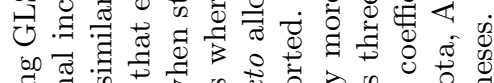

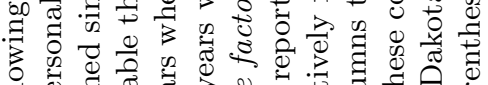

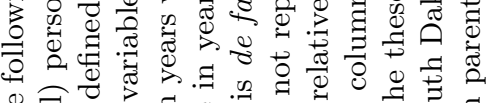

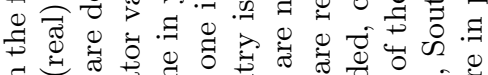

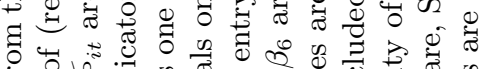

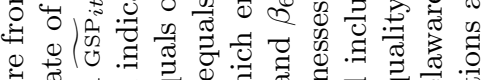

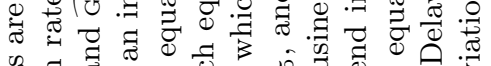

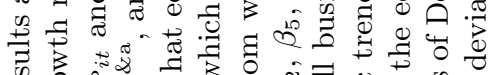

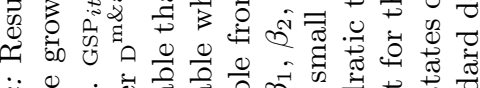

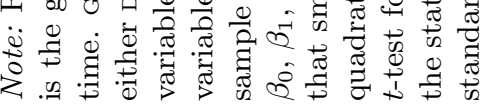


Table 12:

Banking Deregulation and the Sensitivity of Personal Income Components to Output. Robustness test: Omitting Alaska and Wyoming

\begin{tabular}{|c|c|c|c|c|c|c|c|c|}
\hline & \multicolumn{4}{|c|}{ Proprietors' Income } & \multicolumn{2}{|c|}{ Wages } & \multicolumn{2}{|c|}{ Int., Div. \& Rent } \\
\hline & (1) & $(2)$ & $(3)$ & $(4)$ & $(5)$ & $(6)$ & (7) & $(8)$ \\
\hline GSP & $\begin{array}{l}324.0 \\
(41.8)\end{array}$ & $\begin{array}{l}304.1 \\
(39.2)\end{array}$ & $\begin{array}{l}342.2 \\
(51.6)\end{array}$ & $\begin{array}{l}298.5 \\
(47.2)\end{array}$ & $\begin{array}{l}52.7 \\
(4.0)\end{array}$ & $\begin{array}{l}55.7 \\
(4.0)\end{array}$ & $\begin{array}{l}23.2 \\
(2.7)\end{array}$ & $\begin{array}{r}23.3 \\
(2.6)\end{array}$ \\
\hline \multicolumn{9}{|c|}{ INTRASTATE DEREGULATION } \\
\hline $\mathrm{GSP} \cdot \mathrm{D}^{\mathrm{m} \& \mathrm{a}}$ & $\begin{array}{r}-174.8 \\
(61.8)\end{array}$ & $\begin{array}{l}- \\
-\end{array}$ & $\begin{array}{c}-234.2 \\
(64.2)\end{array}$ & $\begin{array}{l}- \\
-\end{array}$ & $\begin{array}{l}19.1 \\
(4.9)\end{array}$ & - & $\begin{array}{c}7.4 \\
(6.1)\end{array}$ & $\begin{array}{l}- \\
-\end{array}$ \\
\hline $\mathrm{GSP} \cdot \mathrm{D}^{\text {novo }}$ & $\begin{array}{l}- \\
-\end{array}$ & $\begin{array}{c}-109.5 \\
(63.6)\end{array}$ & $\begin{array}{l}- \\
-\end{array}$ & $\begin{array}{c}-102.2 \\
(62.4)\end{array}$ & $\begin{array}{l}- \\
-\end{array}$ & $\begin{array}{c}7.2 \\
(4.6)\end{array}$ & $\begin{array}{l}- \\
-\end{array}$ & $\begin{array}{l}10.7 \\
(7.2)\end{array}$ \\
\hline \multicolumn{9}{|c|}{ INTERSTATE DEREGULATION } \\
\hline $\mathrm{GSP} \cdot \mathrm{D}^{\text {inter }}$ & $\begin{array}{l}- \\
-\end{array}$ & $\begin{array}{c}-115.6 \\
(47.9)\end{array}$ & $\begin{array}{l}- \\
-\end{array}$ & $\begin{array}{c}-111.5 \\
(58.3)\end{array}$ & $\begin{array}{l}- \\
-\end{array}$ & $\begin{array}{l}-5.8 \\
(4.2)\end{array}$ & $\begin{array}{l}- \\
-\end{array}$ & $\begin{array}{l}-10.4 \\
(7.2)\end{array}$ \\
\hline GSP $\cdot D^{\text {reci }}$ & $\begin{array}{l}-83.8 \\
(46.7)\end{array}$ & $\begin{array}{l}- \\
-\end{array}$ & $\begin{array}{l}-37.5 \\
(46.2)\end{array}$ & $\begin{array}{l}- \\
-\end{array}$ & $\begin{array}{c}-21.5 \\
(5.6)\end{array}$ & $\begin{array}{l}- \\
-\end{array}$ & $\begin{array}{l}-9.8 \\
(7.7)\end{array}$ & $\begin{array}{l}- \\
-\end{array}$ \\
\hline \multicolumn{9}{|c|}{ QUADRATIC TREND } \\
\hline GSP $\cdot$ TREND & $\begin{array}{l}- \\
-\end{array}$ & $\begin{array}{l}- \\
-\end{array}$ & $\begin{array}{c}0.6 \\
(2.9)\end{array}$ & $\begin{array}{l}-0.9 \\
(2.6)\end{array}$ & - & - & $\begin{array}{l}- \\
-\end{array}$ & $\begin{array}{l}- \\
-\end{array}$ \\
\hline GSP $\cdot$ TREND $^{2}$ & $\begin{array}{l}- \\
-\end{array}$ & $\begin{array}{l}- \\
-\end{array}$ & $\begin{array}{l}-0.7 \\
(0.2)\end{array}$ & $\begin{array}{l}-0.6 \\
(0.2)\end{array}$ & $\begin{array}{l}- \\
-\end{array}$ & $\begin{array}{l}- \\
-\end{array}$ & $\begin{array}{l}- \\
-\end{array}$ & $\begin{array}{l}- \\
-\end{array}$ \\
\hline $\mathrm{R}^{2}$ & 0.05 & 0.05 & 0.06 & 0.06 & 0.47 & 0.45 & 0.09 & 0.09 \\
\hline
\end{tabular}

Note: Results are from the following GLS regressions: $\widetilde{\mathrm{INC}_{i t}}=\alpha_{i}+\beta_{0} \widetilde{\mathrm{GSP}}_{i t}+\beta_{1} \mathrm{D}_{i t}^{k}+\beta_{2} \mathrm{D}_{i t}^{m}+$ $\beta_{3} \widetilde{\mathrm{GSP}}_{i t} \cdot \mathrm{D}_{i t}^{k}+\beta_{4} \widetilde{\mathrm{GSP}}_{i t} \cdot \mathrm{D}_{i t}^{m}+\beta_{5} t+\beta_{6} t^{2}+\epsilon_{i t}$. INC $i t$ is the growth rate of (real) personal income components (per capita) in state $i$ in period $t$ and $\widetilde{\mathrm{INC}}_{i t}$ is $\mathrm{INC}_{i t}$ minus its mean across states minus its mean across time. GSP $i t$ and $\widetilde{\mathrm{GSP}}_{i t}$ are defined similarly using gross state product. In columns (1)-(4), $\mathrm{INC}_{i t}$ is proprietors' income, in columns (5) and (6) - wages, and in columns (7) and (8) -income from dividends, interest, and rent. $\alpha_{i}$ (not reported) is a state fixed effect. $\mathrm{D}_{i t}^{k}$ is a measure of intrastate deregulation: either $\mathrm{D}^{\mathrm{m} \& \mathrm{a}}$, an indicator variable that equals one in years where statewide branching by mergers and acquisitions were permitted, or $\mathrm{D}^{\text {novo }}$, an indicator variable that equals one in years when statewide de novo branching was permitted. $\mathrm{D}_{i t}^{m}$ is a measure of interstate deregulation: either $\mathrm{D}^{\mathrm{inter}}$, an indicator variable which equals one in years where entry by out-ofstate bank holding companies were permitted, or $\mathrm{D}^{\text {reci }}$, the fraction of (outside) states in the sample from which entry is de facto allowed, taking into account whether the reciprocity constraint for each individual outside state is binding or not. $\beta_{1}$ and $\beta_{2}$ are not reported. The sample is 1970-2001; District of Columbia and the states of Delaware, South Dakota, Alaska, and Wyoming are excluded. Coefficients and standard errors are multiplied by 100. GLS clustering-robust standard deviations are in parentheses. Number of observations is 1472 . 
Table 13:

Banking Deregulation and Income Insurance.

Robustness test: OLS estimation

\begin{tabular}{|c|c|c|c|c|}
\hline & $(1)$ & $(2)$ & $(3)$ & $(4)$ \\
\hline \multirow[t]{2}{*}{ GSP } & $\begin{array}{l}37.7 \\
(1.7)\end{array}$ & $\begin{array}{c}37.4 \\
(1.6)\end{array}$ & $\begin{array}{l}35.4 \\
(2.3)\end{array}$ & $\begin{array}{r}40.1 \\
(2.2)\end{array}$ \\
\hline & \multicolumn{4}{|c|}{ INTRASTATE DEREGULATION } \\
\hline $\mathrm{GSP} \cdot \mathrm{D}^{\mathrm{m} \& \mathrm{a}}$ & $\begin{array}{l}20.0 \\
(2.6)\end{array}$ & - & $\begin{array}{c}18.9 \\
(2.6)\end{array}$ & $\begin{array}{l}- \\
-\end{array}$ \\
\hline \multirow[t]{2}{*}{$\mathrm{GSP} \cdot \mathrm{D}^{\text {novo }}$} & $\begin{array}{l}- \\
-\end{array}$ & $\begin{array}{l}24.5 \\
(2.5)\end{array}$ & $\begin{array}{l}- \\
-\end{array}$ & $\begin{array}{r}26.7 \\
(2.4)\end{array}$ \\
\hline & \multicolumn{4}{|c|}{ INTERSTATE DEREGULATION } \\
\hline GSP $\cdot D^{\text {inter }}$ & - & $\begin{array}{l}13.4 \\
(2.8)\end{array}$ & - & $\begin{array}{c}-0.1 \\
(3.9)\end{array}$ \\
\hline \multirow[t]{3}{*}{$\mathrm{GSP} \cdot \mathrm{D}^{\mathrm{reci}}$} & $\begin{array}{l}19.9 \\
(3.2)\end{array}$ & $\begin{array}{l}- \\
-\end{array}$ & $\begin{array}{l}19.5 \\
(4.2)\end{array}$ & $\begin{array}{l}- \\
-\end{array}$ \\
\hline & \multicolumn{4}{|c|}{ QUADRATIC TREND } \\
\hline & $\begin{array}{c}\text { no } \\
0.65\end{array}$ & $\begin{array}{c}\text { no } \\
0.65\end{array}$ & $\begin{array}{c}\text { yes } \\
0.67\end{array}$ & $\begin{array}{r}\text { yes } \\
0.68\end{array}$ \\
\hline
\end{tabular}

Note: Results are from the following OLS regressions: $\widetilde{\mathrm{GSP}_{i t}}-\widetilde{\mathrm{PINC}}_{i t}=\alpha_{i}+\beta_{0} \widetilde{\mathrm{GSP}_{i t}}+\beta_{1} \mathrm{D}_{i t}^{k}+\beta_{2} \mathrm{D}_{i t}^{m}+$ $\beta_{3} \widetilde{\mathrm{GSP}}_{i t} \cdot \mathrm{D}_{i t}^{k}+\beta_{4} \widetilde{\mathrm{GSP}} i t \cdot \mathrm{D}_{i t}^{m}+\beta_{5} t+\beta_{6} t^{2}+\epsilon_{i t} . \mathrm{PINC}_{i t}$ is the growth rate of (real) personal income (per capita) in state $i$ in period $t$ and $\widetilde{P I N C}_{i t}$ is PINC $_{i t}$ minus its mean across states minus its mean across time. GSP $i t$ and $\widetilde{\text { GSP }}_{i t}$ are defined similarly using gross state product. $\alpha_{i}$ (not reported) is a state fixed effect. $\mathrm{D}_{i t}^{k}$ is a measure of intrastate deregulation: either $\mathrm{D}^{\mathrm{m} \& \mathrm{a}}$, an indicator variable that equals one in years where statewide branching by mergers and acquisitions were permitted, or $\mathrm{D}^{\text {novo }}$, an indicator variable that equals one in years when statewide de novo branching was permitted. $\mathrm{D}_{i t}^{m}$ is a measure of interstate deregulation: either $\mathrm{D}^{\text {inter }}$, an indicator variable which equals one in years where entry by out-of-state bank holding companies were permitted, or $\mathrm{D}^{\text {reci }}$, the fraction of (outside) states in the sample from which entry is de facto allowed, taking into account whether the reciprocity constraint for each individual outside state is binding or not. $\beta_{1}, \beta_{2}, \beta_{5}$, and $\beta_{6}$ are not reported. The sample is 1970-2001; District of Columbia and the states of Delaware and South Dakota are excluded. GLS clustering-robust standard deviations are in parentheses. Coefficients and standard errors are multiplied by 100. Number of observations is 1536 . 


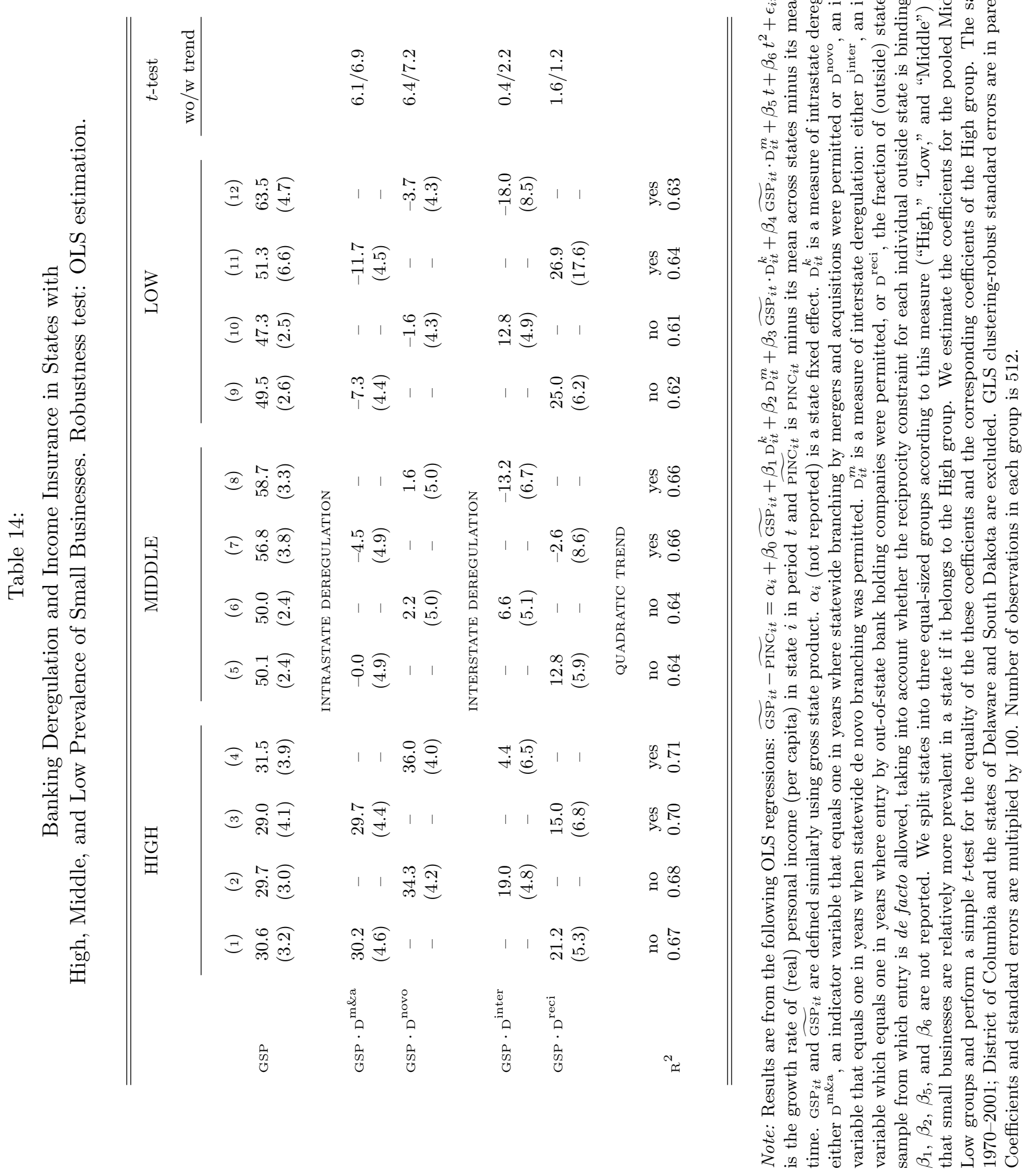


Figure 1: Reciprocal Interstate Banking Deregulation

\section{A. Average U.S.}

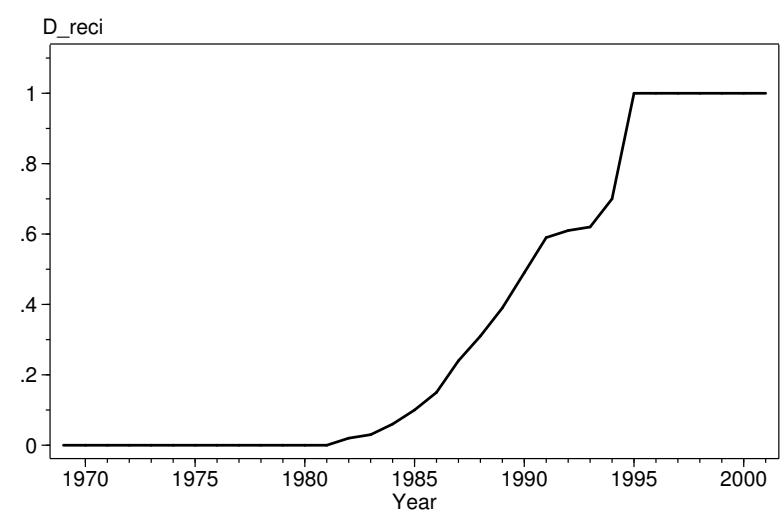

C. Michigan

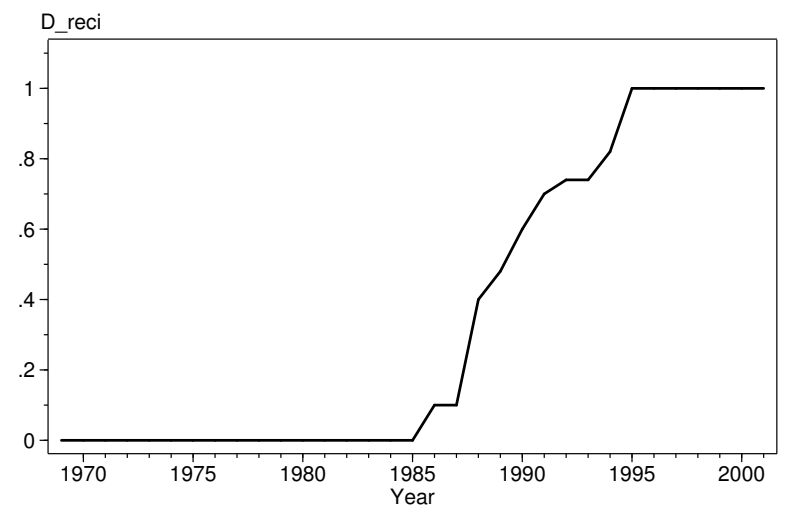

B. Idaho

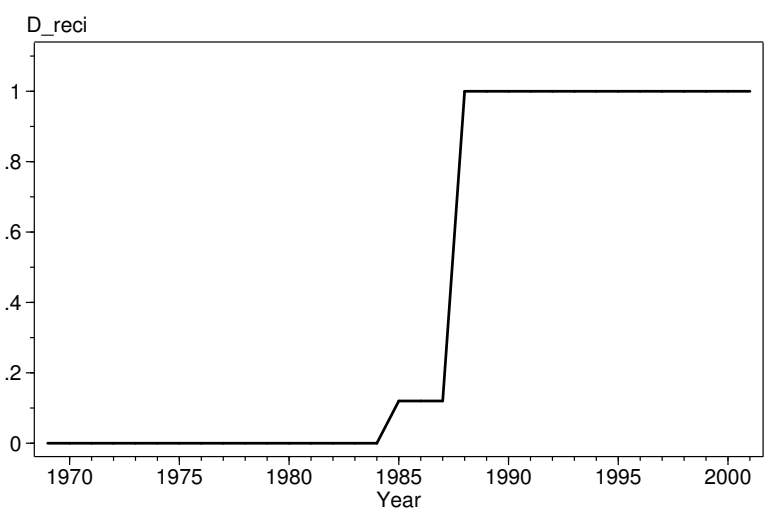

D. New York

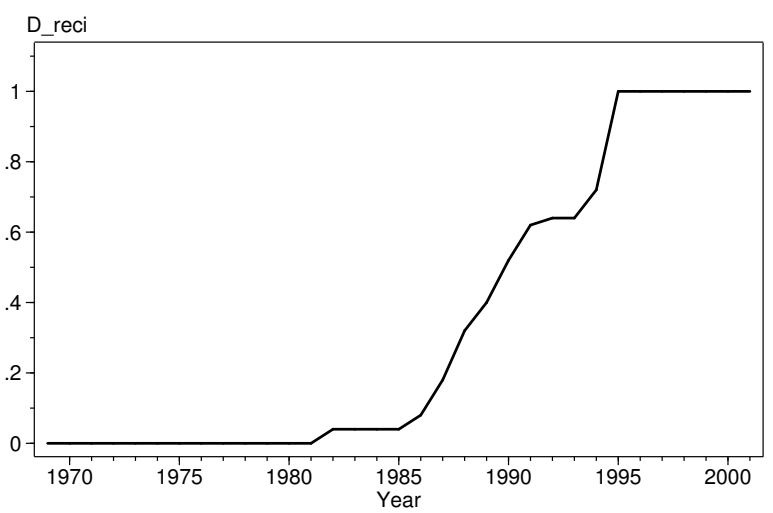

Note: The figure shows the interstate deregulation measure D_reci defined as the fraction of (outside) states in the sample from which entry is de facto allowed, taking into account whether the reciprocity constraint for each individual outside state is binding or not. The variable takes values between zero and one, where the value of one means that banks from any other state are permitted to enter, and the value zero means that banks from no other state may enter. Sample: 1970-2001. The states of Delaware and South Dakota are excluded. 
Figure 2: Average and State-Specific Growth Rates of GSP and Personal Income

A. Average U.S.

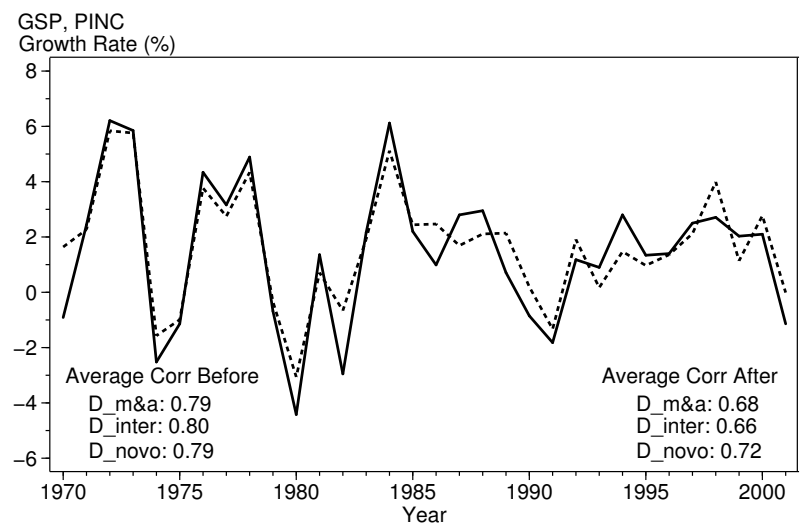

C. Michigan

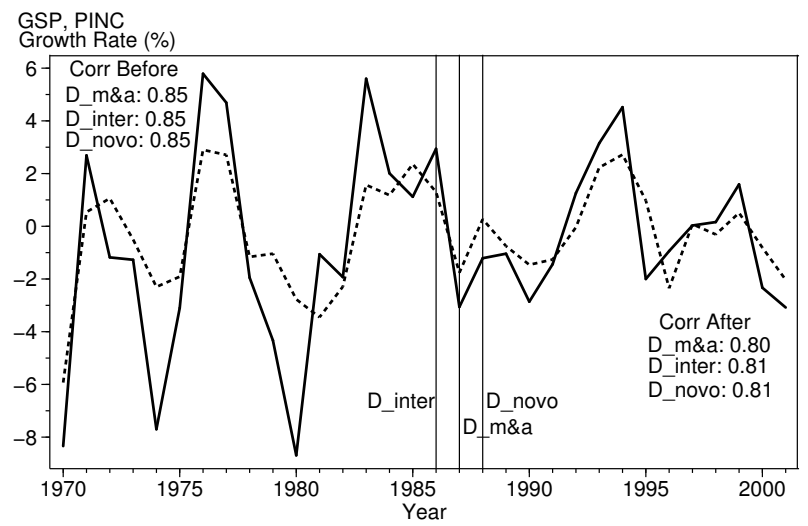

B. Idaho

GSP, PINC

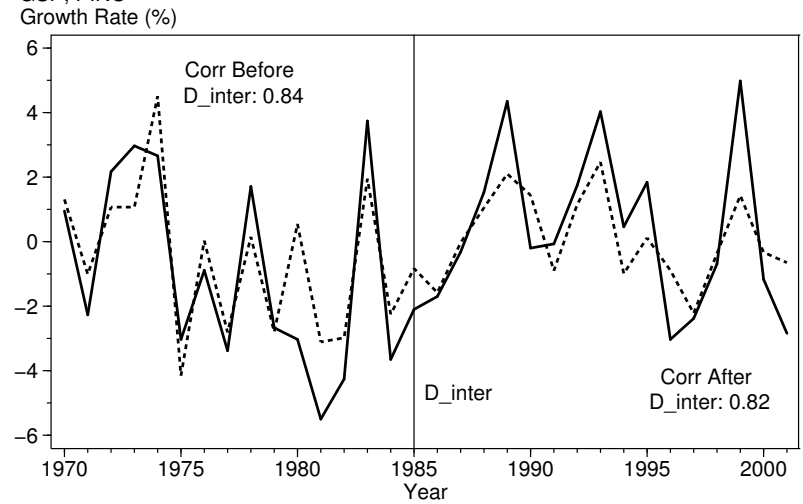

D. New York

GSP, PINC

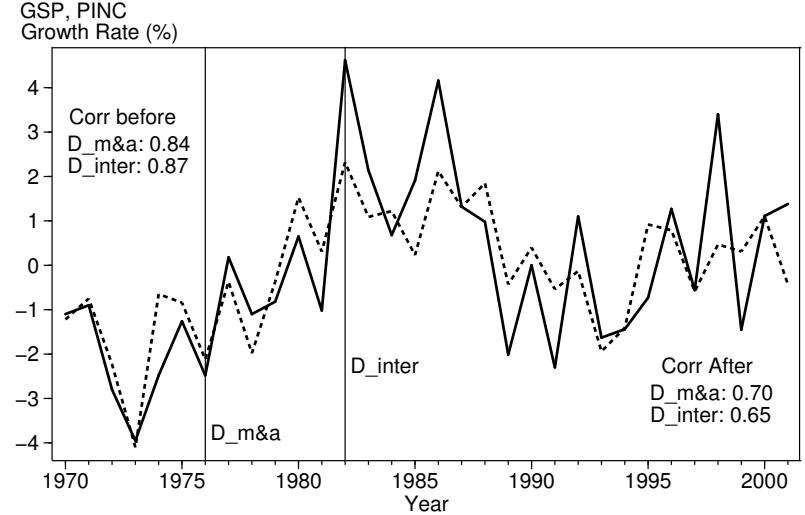

Note: The figure shows growth rates of Gross State Product (GSP) (solid line) and State Personal Income (PINC) (dotted line) for the average of U.S. states (Panel A), and state-specific (state minus average) growth rates for three arbitrary states (Panels B-D). Vertical lines correspond to the dates of deregulation, where D_m\&a denotes the year when statewide branching by mergers and acquisition was permitted, D_inter denotes the year when interstate banking were permitted, and D_novo denotes the year when statewide de novo branching was permitted. In Panels B-D, the left side of each panel states the correlation coefficients between GSP and PINC for the years prior to deregulation and the right side states the correlation coefficients for the years following deregulation. In Panel A, the corresponding correlations are computed as the averages across U.S. states. Sample: 1970-2001. The states of Delaware and South Dakota are excluded. 
Figure 3: Average and State-Specific Growth Rates of GSP and Proprietors' Income

A. Average U.S.

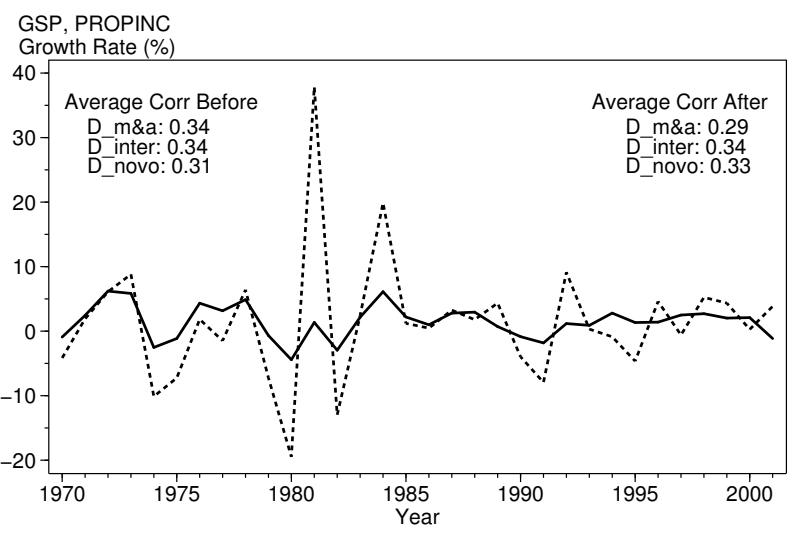

C. Michigan

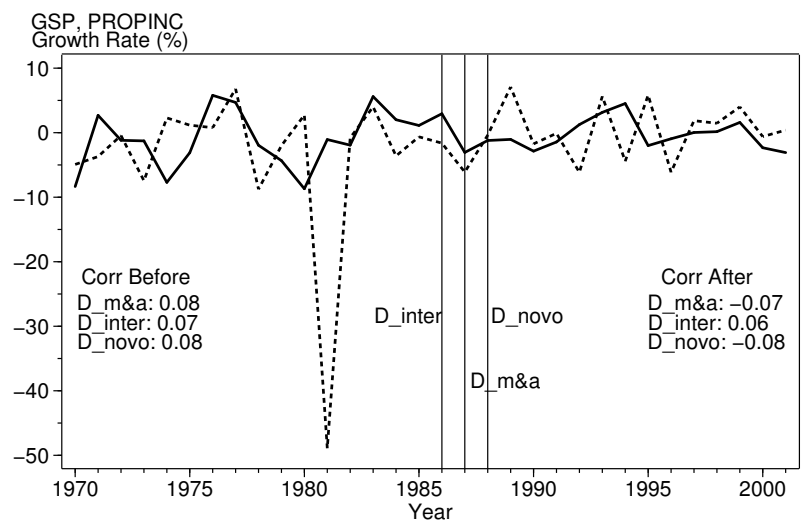

B. Idaho

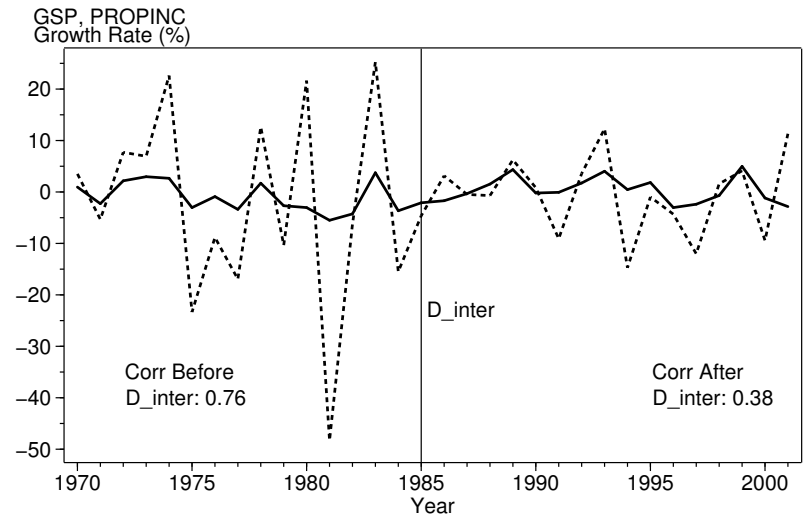

D. New York

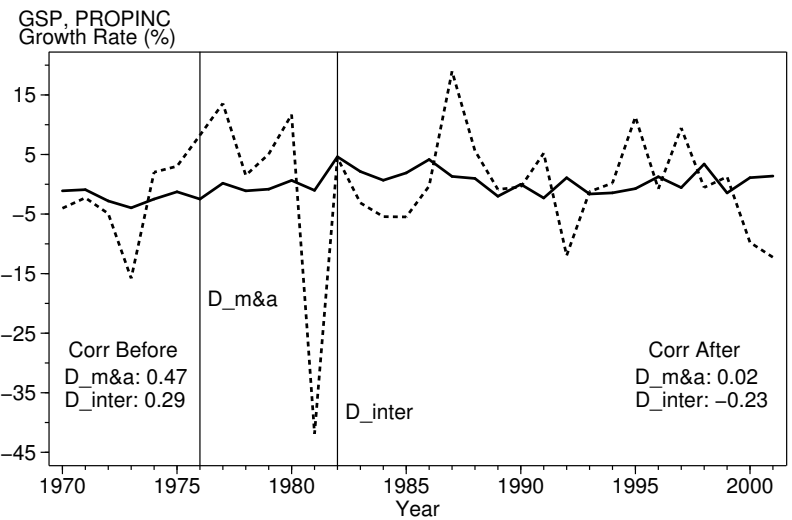

Note: The figure shows growth rates of Gross State Product (GSP) (solid line) and State Proprietors' Income (PROPINC) (dotted line) for the average across U.S. states (Panel A), and state-specific (state minus average) growth rates for three arbitrary states (Panels B-D). Vertical lines correspond to the dates of deregulation, where D_m\&a denotes the year when statewide branching by mergers and acquisition was permitted, D_inter denotes the year when interstate banking were permitted, and D_novo denotes the year when statewide de novo branching was permitted. In Panels B-D, the left side of each panel states the correlation coefficients between GSP and PINC for the years prior to deregulation and the right side states the correlation coefficients for the years following deregulation. In Panel A, the corresponding correlations are computed as the averages across U.S. states. Sample: 1970-2001. The states of Delaware and South Dakota are excluded. 